\title{
Studies of Ant-Following Birds North of the Eastern Amazon
}

\author{
YOSHIKA ONIKI \\ EDWIN O. WILLIS \\ Department of Biology, Princeton \\ University
}

\begin{abstract}
Birds that prey on arthropods flushed by army ants north of the eastern Amazon were studied at Serra do Navio and Reserva Ducke (Brazil) and at Nappi Creek and Bartica (Guyana). Regular ant. followers are two medium-sized antbirds (Percnostola rufifrons and Gymnopithys rufigula) and two smaller cnes (Pithys albifrons and Hylophylax poecilonota), pius five woodcreepers of differing sizes (from very large Hylexetastes perrotti through Dendrocolaptes picumnus, D. certhia, and Dendrocincla merula to medium-sized Dendrocincla fuliginosa). Four other regular ant-followers occur in the region but were not found at the study areas. Forty-five species of casual or nonprofessional ant-followers, including 16 antbirds, 5 woodcreepers, and 5 manakins, also were recorded. Perenostola rufifrons tends to be at the forest edge or in second growth. Pithys albifrons works around Gymnopithys rufigula, Hylophylax poecilonota peripheral to both, in the forest interior. The large Dendrocolaptes picumnus and mediumlarge Dendrocincla merula often capture prey near the ground, like antbirds. Unlike antbirds, which use vertical or horizontal slender perches, the woodcreepers use thick vertical perches. Dendrocolaptes certhia and Dendrocincla fuliginosa also tend to capture prey high over the ground-foraging antbirds. The woodcreepers tend to forage lower at midday. Hylexetastes perrotti is rare, and overlaps strongly with $\mathbf{D}$. picumnus. There is fairly large overlap among the 9 professional ant-followers, and large ones chase away smaller ones. Nonprofessional birds tend to forage briefly or peripherally when or slightly after the professional species are active. They also forage above the antbirds and below or above the woodcreepers, and concentrate at forest edges or in second growth" The guild of ant-following birds in this region differs fairly widely from guilds in Panamá and at Belém, Brazil; the absence of large antbirds and the predominance of large woodcreepers north of the Amazon are the major differences.
\end{abstract}

\section{INTRODUCTION}

In neotropical forests, many species of birds prey on arthropods fleeing from advancing swarms of army ants. In different regions. different "guilds" (Root, 1967) or assemblages of species follow the army ants. Johnson (1954), Slud (1960), and Willis (1960, 1967) report on some guilds of ant-following birds of Caribbean Central America. In Amazonia, antfollowing guilds differ across the major rivers (Willis, 1968b, 1969). Here we give the first report, except for a few notes in Beebe, Hartley, and Howes (1917) and in Haverschmidt (1968). on the ant-following birds of the wide forests north of the eastern Amazon.

\section{STUDY AREAS}

To observe these guilds, Oniki visited Serra do Navio (Amapá, Brazil) 15 April to 19 May 1968 and Willis visited Nappi Creek (Guyana) 24 December 1961 to 4 January 1962, Bartica (Guyana) 14-15 January 1962, and Reserva Ducke (Amazonas, Brazil) 9 to 12 March 1966.

Serra do Navio $\left(0^{\circ} 55^{\prime} \mathrm{N}, 52^{\circ} 01^{\prime} \mathrm{W}\right)$, a hilly manganese district managed by ICOMI (Indústria e Comércio de Minérios S.A.), is at 90 to $360 \mathrm{~m}$ elevation on the northeast side of the Amapari River, an affluent of the Araguari River (Fig. 1). Rainfall averages $2310 \mathrm{~mm}$ yearly; it was $191 \mathrm{~mm}$ in April and $345 \mathrm{~mm}$ in May, 1968. There are areas of second growth near forest areas undisturbed except for mining roads and fallen trees. Rodrigues (1963) describes some of the rich upland flora.

Reserva Ducke ( $3^{\circ} 08^{\prime} \mathrm{S}$ and $60^{\circ} 02^{\prime} \mathrm{W}$ ) is a forest reserve of the Instituto Nacional de Pesquisas da Amazônia (INPA) on rolling land with 


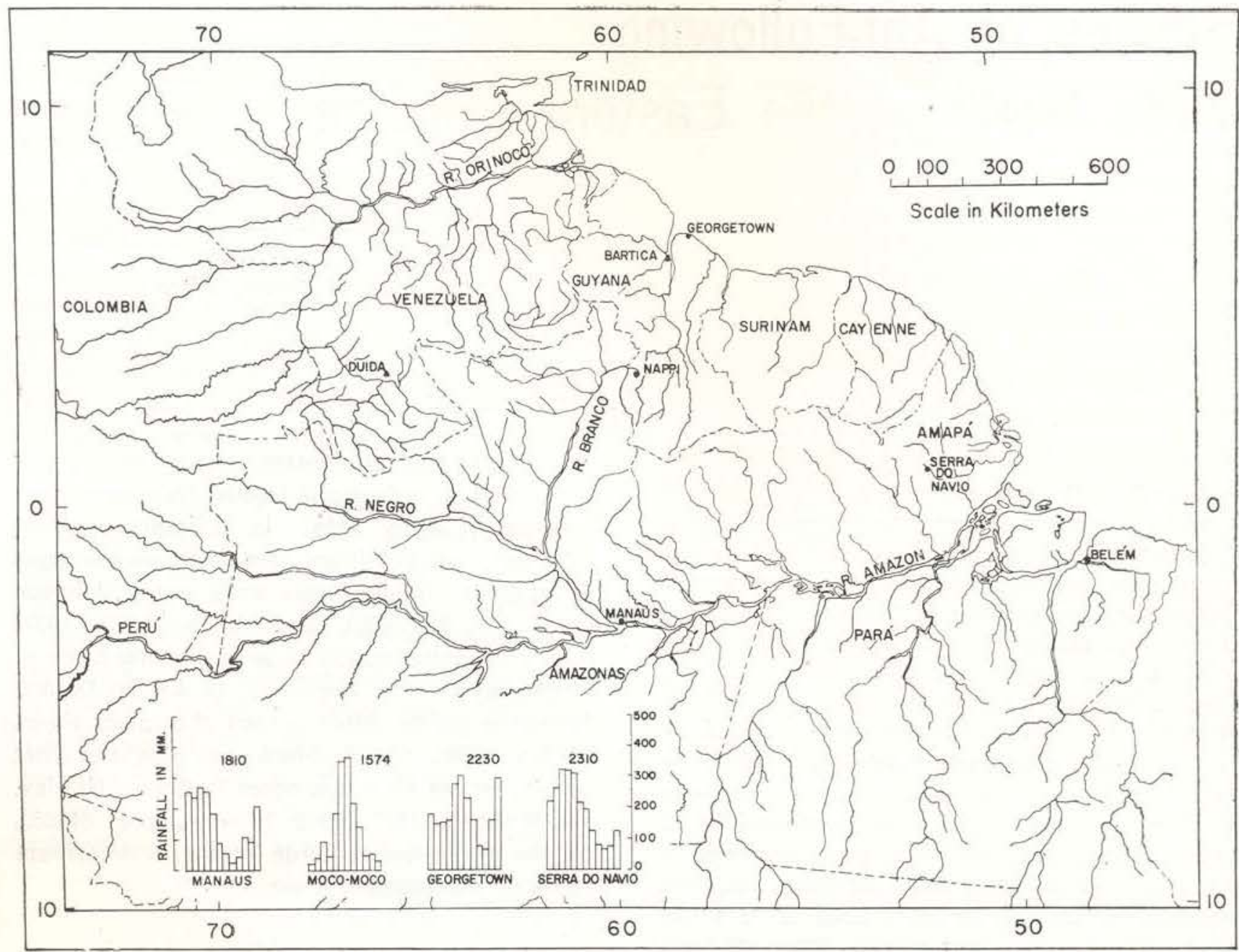

Fig. 1 - Northeastern South America, showing the study areas and average monthly and yearly rainfalls at nearby stations. Moco-Moco is just west of Nappi, Manaus just west of Reserve Ducke.

scattered swampy streams near $\mathrm{Km} 26$ on the Manaus-Itacoatiara road. It is about $80 \mathrm{~m}$ elevation. The rich upland forest (Araújo, 1967) is relatively undisturbed except for some small clearings, some areas from which undergrowth has been cleared, and a grid of compass-line trails.

Nappi Creek (about $3^{\circ} 17^{\prime} \mathrm{N}, 59^{\circ} 39^{\prime} \mathrm{W}$ ) is by a settlement of Macusi Indians at $200 \mathrm{~m}$ elevation on the flats and lower slopes of the northern base of Kanaku Mountains. The latter and nearby flats form a forested peninsula into the Rupununi savannahs, which are an eastern extension of the Venezuelan Ilanos and Brazilian campos cerrados (Gilliard, 1962). There is a major rainy sason May to September, and near the mountains cloud cover and occasional rain in the dry season perhaps reduce annual droughts and permit forest development (Frost, 1968). A road, clearings, and patches of second growth interrupt the forest along the main creek, which flows to the Rio Takatu and thence to the Rio Branco, the Rio Negro, and the Amazon.

The road from Bartica south to Potaro passes over terra-firme forested sandy plains at an elevation of $20 \mathrm{~m}$ or so. Birds were accompanying ants 14 January near the 24-mile point $\left(6^{\circ} 10^{\prime} \mathrm{N}, 58^{\circ} 41^{\prime} \mathrm{W}\right)$ and the next day near the 3-mile point $\left(6^{\circ} 21^{\prime} \mathrm{N}, 58^{\circ} 40^{\prime} \mathrm{W}\right)$. Forestry trails and logging trails for greenheart (Ocotea rodeiai) grid the area at 24 miles, and there are extensive areas of clearings and second growth as well at 3 miles, but otherwise the extensive forest are little disturbed. Occasional streams provide minor swampy areas in flowing 
to the Mazaruni Piver to the west. The rainy seasons are November to January and May to August, as at nearby Georgetown.

\section{ARMY ANTS}

From Mexico to Argentina, Eciton burchelli is the major species of army ant followed by birds (Willis, 1967). A colony forms a swarm up to $20 \mathrm{~m}$ across, which moves up to $200 \mathrm{~m}$ a day over the leaf litter and probes briefly up trunks of palms and other trees above the ground. Schneirla (1957) and Rettenmeyer (1963) describe the biology of the species. A colony stays in one bivouac or nest site for about three weeks of a "statary" period, then changes the bivouac site every night for the two weeks of a "nomadic" period. During each statary period, successive raids of the colony radiate like spokes from a wheel; but on sorne days the ants do not raid at all. During the nomadic period, raiding is daily and individual ant-following birds often depend on a single colony.

Other species of army ants are less important for birds. Labidus praedator is often followed from Mexico to Argentina, but is so irregular at raiding that it is not very important for birds even where it is common (Willis, 1967). In Amazonia, straggling swarms of Eciton rapax occasionally attract birds (Willis, 1968a).

During our studies, Oniki for the first time recorded birds following a swarm raid of the tiny black Labidus spininodis. The ants were swarming under leaf litter and perhaps underground about $75 \mathrm{~m}$ from the inactive statary bivouac of a colony of Eciton burchelli; the previous day a statary raid had passed nearby An adult and young Rufous-throated Antbird (Gymnopithys rufigula), one Chestnut-belted Gnateater (Conopophaga aurita), and a Rufousbellied Antwren (Myrmotherula guttata) followed the $L$. spininodis raid, but a male Scale-backed Antbird (Hylophylax poecilonota) and a Plaınbrown Woodcreeper (Dendrocincla fuliginosa) ignored the raid and waited near the statary bivouac. [Bird names herein follow Meyer de Schauensee, 1966.]

\section{MATERIALS AND METHODS}

We watched with $7 \times 35 \mathrm{~mm}$ or $8 \times 40 \mathrm{~mm}$ binoculars from 5 to $20 \mathrm{~m}$ behind swarm raids of colonies of Eciton burchelli in both nomadic and statary phases. Most birds became tame to moderately tame after a few hours of observation, as long as we did not move through or ahead of the ants. Oniki watched colonies (A-1, A-2, A-3) for a total of 117 hours. Willis watched four colonies (C-1 to C-4) at Nappi for a total of 52.5 hours, two (B-1, B-2) near Bartica for 1.6 hours, and four (D-1 to D-4) at Reserva Ducke for 8.9 hours.

We recorded in field notes data on foraging perches used, foraging motions at different heights, and calls and other behavior of the birds. A bird was listed as following ants only if it actively foraged around a place where ants were flushing prey. Birds that seemed to ignore the ants were recorded only as "passing birds that ignored ants" and are not listed in the species accounts below.

\section{BIRD SPECIES THAT FOLLOW ANTS}

North of the eastern Amazon there are probably 13 kinds of "professional" antfollowers, ones that depend on following army ants for 50 or more percent of their food. We did not encounter four of these species in the study areas. Neither of us has seen the Rufous-winged Ground-Cuckoo (Neomorphus rufipennis, Cuculidae), which extends from southern Venezuela and northern Brazil east to the Essequibo River in Guyana (Snyder, 1966). It may be conspecific with the Rufous-vented Ground-Cuckoo (Neomorphus geoffroyi), which normally runs around swarms of army ants like a forest roadrunner (Geococcyx sp.) in vinetangled riverine or second-growth forests from Nicaragua (Howell, 1957) to central Brazil.

The Black-spotted Bare-Eye (Phlegopsis nigromaculata, Formicariidae) barely crosses north of the Amazon near Macapá, Amapá (Novaes, 1957), and the Rufous-winged Bare-Eye (Phlegopsis erythroptera) of western Amazonia barely crosses the Rio Negro in southern Venezuela (Phelps and Phelps, 1963). Both species are persistent ant-followers in regions where we have studied them. 
Although we have both found the Grayheaded Tanager (Eucometis penicillata) with army ants in other regions, and it is recorded from the Guianas to northeastern Brazil, we did not encounter it on any of the study areas. At Belém. Oniki found it mainly in várzea forest (flooded periodically by tides), occasionally in second growth; in Surinam it seems to occupy swampy areas (Haverschmidt, 1968). At Belém, it sometimes occurs away from ants and in the wandering interspecific flocks. Probably it is restricted to swampy or isolated habitats in Amazonia.

We encountered the nine remaining species, five woodcreepers (Dendrocolaptidae) and four antbirds (Formicariidae), on our study areas. We found eight species at Serra do Navio, Reserva Ducke, and Nappi but only six at Bartica, possibly because of the brief visit. [In 1972, Willis found the ninth species also at Reserva Ducke]. Table 1 gives average weights and culmen lengths for these professional antfollowers as well as their places in the interspecific dominance hierarchy over ants and the habitats and levels at which they foraged. "Mobility" refers to the speed with which a bird could change from one swarm of ants to another, " 1 " birds being very rapid and " 3 " birds least rapid. Data on bird weights are mostly from Haverschmidt (1968), on bill lengths from specimens in the American Museum of Natural History.

In addition to the "professional" antfollowers, we recorded 45 species of "nonprofessional" or "amateur" birds following swarms; 20 were at Serra do Navio, 5 at Reserva Ducke, 31 at Nappi, and 2 at Bartica. Sixteen are antbirds, five are woodcreepers, and five are manakins (Pipridae). These species, as well as additional species recorded by other workers in the region, are discussed after the professional ant-followers.

\section{PROFESSIONAL ANT-FOLLOWERS}

Plain-brown Woodcreepers (Dendrocincla fuliginosa). Moderately common ant-followers in all study areas, as they are over most of their range from Honduras to Argentina except for Trinidad, where in the absence of other professional ant-followers they are abundant
(Willis, 1966). Plain-brown Woodcreepers wander around the swarm or around the bivouac before the swarm starts. They normally perch on vertical trunks of moderate size (Appendices 1. 2, 3), seldom on diagonal branches. They often perch high, but fly to low perches and get much of their food from the ground when dominant woodcreepers or active low-foraging antbirds are absent (Willis, 1966). When competitors are present, the woodcreepers get food at many heights and in many places, as at the bases of trees, on trunks, under leaves, or in the air. They capture food mainly by sallying, or on the wing; but occasionally one pecks prey from a nearby surface.

When several Plain-brown Woodcreepers follow a raid, the dominant bird supplants and chases the others at times. At times Blackbanded Woodcreepers fight with one or supplant it, as do the other large or medium-sized woodcreepers (Buff-throated at Nappi, Barred and Red-billed in all areas, White-chinned at Reserva Ducke).

A roosting bird in capoeira (second growth) near colony A-1 (Oniki, 1970) was not observed to follow the colony. In this region, we observed the species mainly in forest, even though it readily enters capoeira in Trinidad (Willis, 1966) and at Belém.

Like the following four species, these woodcreepers are sometimes away from ants but do not seem to catch much prey. They usually wait, look, and sally to vegetation or debris for large arthropods or fly to a new observation post.

White-chinned Woodcreeper (Dendrocincla $m$. merula). Moderately common ant-follower at Reserva Ducke. White-chinned Woodcreepers usually stay near the ground over ants, mostly waiting on vertical sapling and tree trunks well below Plain-brown Woodcreepers and darting to the ground for prey. They are fast-moving and timid when a human appears, and call repeatedly or disappear. They move rapidly from one site to another, traveling at 2 to $5 \mathrm{~m}$ up. Mobility perhaps allows them to evade the domineering large woodcreepers and the hopping or clinging antbirds that take over from woodcreepers in many parts of Amazonia. 
At Reserva Ducke, merula sometimes fought or chased with squealing noises or series of alarm notes, suggesting an anti-social separation of the sexes as in most species of Dendrocincla. White-chinned Woodcreepers supplanted Rufous-throated and White-plumed Antbirds, and kept the smaller Plain-brown Woodcreepers from moving down on several occasions.

Barred Woodcreeper (Dendrocolaptes c. certhia). - Regular in small numbers at Nappi, especially near the borders of the forest; seldom seen elsewhere. From Mexico to Brazil this woodcreeper is commonest in patchy woodland or at forest borders or in woodland of intermediate age, but it occurs in tall forest in smalt numbers.

At both Nappi and Serra do Navio it foraged mainly by waiting on medium-sized tree trunks 2 to $10 \mathrm{~m}$ up until ants flushed insects on the trunk or nearby leaves and petioles; it then sallied to the insects and snapped them off with brief hovering or hitched to them and pecked them off. Often large prey is taken; it is flailed on tree trunks, or chewed and shaken vigorously in the bill. Little prey comes from the ground, perhaps in part because Black-banded Woodcreepers and antbirds take most prey there. A foraging Barred Woodcreeper moves frequently, hitching short distances up or down trunks or fiying to a new trunk 3 to $4 \mathrm{~m}$ away after a few seconds of waiting at each site.

These woodcreepers supplant or ignore the smaller Plain-brown and Chestnut-rumped Woodcreepers, evade or are chased by the larger Black-banded, Buff-throated, and Red-billed Woodcreepers. Often a Barred quickly hitches around behind a tree trunk whenever one of the larger woodcreepers flies nearby; it soon deserts the area. We did not seen any interactions with antbirds or with White-chinned Woodcreepers.

Black-banded Woodcreeper (Dendrocolaptes p. picumnus). - One to three individuals were occasionally at swarms in forest in all study areas. - Black-banded Woodcreepers generally perch low on vertical trunks, infrequently on the upper or under sides of diagonal branches, usually ones $10-15 \mathrm{~cm}$ in diameter and hence slightly smaller than those favored by Barred
Woodcreepers and larger than those used by antbirds.

A foraging bird occasionally hitches up or ciown a trunk, peering in crevices of the bark, but normally it waits and looks about 15 to 180 seconds per perch, then flies to another low trunk or hitches up to a new perch on the same trunk. Most flights from trunk to trunk are between 1 and $6 \mathrm{~m}$ long, seldom further. It joins actively feeding groups of Plain-brown and Barred Woodcreepers high above the ground when the ants climb a liana-covered or dead tree. At such times it sallies or pecks arthropods off trunks much as do the other species. More often it waits near the ground, peering back over one shoulder or the other and flying clumsily down to capture large prey on the ground or on logs. It thus takes a niche that Barred Woodcreepers sometimes fill in regions, such as lowland Panamá, where Blacktanded Woodcreepers are absent.

Much of the prey is very large, one to two times the beak length : green or brown grasshoppers, dark cockroaches, black ants, lizards, and spiders. One long-horned grasshopper that one dropped to the ground at Serra do Navio was $10 \mathrm{~cm}$ long.

They are occasionally belligerent at swarms, supplanting or chasing nearby Barred, Plain-brown, or Black-banded Woodcreepers, sometimes Rufous-throated or White-plumed Antbirds. The similarly sized but pugnacious Buff-throated Woodcreepers sometimes flee from but sometimes fight with or dominate them, while they retreat from the large Redbilled Woodcreepers.

Red-billed Woodcreeper (Hylexetastes per. rotti). - One to three were at a few swarms of ants. The moderately tame birds we watched stayed 1 to $13 \mathrm{~m}$ up on vertical, moderately thick trunks or flew 2 to $3 \mathrm{~m}$ to other trunks. They sometimes hitched upward or downward, looking for food on the trunk, but often waited looking about for prey. Tamer birds, which Willis observed at Palhão, Pará, foraged mostly by perching near the ground and sallying clumsily to it for large prey; these birds excluded Black-banded Woodcreepers from the central and best foraging zones low over the ants. Probably the usual niche is working 
the zone near the ground, which these birds should be able to monopolize. At our study areas north of the eastern Amazon, they occasionally supplanted Barred or Black-banded Woodcreepers.

White-plumed Antbird (Pithys albifrons). Very common at swarms at all sites, with as many as eight to ten individuals at one swarm. They were the most numerous ant- followers at Serra do Navio, and were only slightly behind the following species in other sites visited.

White-plumed Antbirds perch on low, thin horizontal to vertical branches and stems over the ants, often reversing 180 degrees to look about and dart to the ground in short sallies for prey. They sometimes capture prey on leaves, branches, and trunks. If the insect runs away, the antbird hops after it; if the prey hides it tosses leaves to find it. At times an antbird Ferches near the ground and obtains the food by just swinging down and lunging to peck it. Once Oniki saw a young bird steal prey that ants were carrying. A bird usually eats the prey on the ground or on the perch it returned to, but more often flies away from the ants if other birds are around.

Food was mostly arthropods, such as spiders, grasshoppers, cockroaches, small beetles, and moths; several times white egg sacs of spiders were eaten. Most food items are under twice the length of the bird's exposed beak $(2 x=28 \mathrm{~mm})$.

Adult White-plumed Antbirds readily supplant young, and older young supplant younger ones. Rufous-throated and Black-headed Antbirds supplant these antbirds readily, and occasionally a Black-banded or a White-chinned Woodcreeper supplants or displaces one.

Rufous-throated Antbird (Gymnopithys rufigula). - The commonest bird at swarms at all sites except Serra do Navio, where it was second most common. The species lives only in the area considered by this report, from southern Venezuela east and south to the Rios Negro and Amazon, but the related Whitecheeked Antbird (Gymnopithys leucaspis) west of the Rio Negro may be conspecific (Willis, 1967),

When foraging, Rufous-throated Antbirds wait mostly on low horizontal and vertical perches, especially ones $1-2 \mathrm{~cm}$ in diameter.
They sometimes capture food from low branches and under leaves, but mostly they sally to the ground 10 to $100 \mathrm{~cm}$ from their perches and return to the perches to eat the food or fly to another low perch. We seldom saw one eating prey on the ground among the ants. Occasionally one tosses leaves on the ground. Large prey may be carried away to use the ground or a log as a table for shaking, chewing, and other dissection. It forages much like the Whiteplumed Antbird, but tends to wait longer at each perch and not to move about so rapidly. Food is much the same as for White-plumed Antbirds; it is mostly under two times the exposed beak length $(2 \mathrm{x}=30 \mathrm{~mm})$.

Rufous-throated Antbirds regularly supplant others of their own species (see Willis, 1967, pp. 50-52). They regularly supplant Whiteplumed Antbirds. At Nappi, one supplanted a Warbling Antbird and another displaced a Plainbrown Woodcreeper. Twice there they supplanted Black-headed Antbird females, but once a male Black-headed Antbird supplanted one. One Black-banded Woodecreeper supplanted ane, as once at Serra do Navio, and at Reserva Ducke a White-chinned Woodcreeper did so.

Black-headed Antbird (Percnostola rufitrons). - An uncommon ant-follower that lives mainly in second growth or at dense forest edges. These birds regularly follow army ants but sometimes wander away from them. Foraging birds over ants perch and hop about un the ground or low vertical to horizontal slender branches (often 1.0-2.5 cm diameter), occasionally to $2-3 \mathrm{~m}$ up in dense tangles. Sometimes they wait patiently, but they are more likely to move about and search as they go. Like other antbirds, they often sally to the ground to capture small prey; unlike other antbirds, they peck much prey off the ground by sudden lunges or by hopping pecks. Occasionally one tosses fallen leaves with the beak, does a vertical leap into the air or to an overhead leaf, or pecks prey off dense lianas or leaves above the ground. Prey items noted were small dark beetles, grasshoppers, and cockroaches. In foraging and in favoring second growth it resembles the White-backed Fire-Eye (Pyriglena leuconota) south of the Amazon, but never seems as numerous as that species. 
Black-headed Antbirds readily supplant White-plumed Antbirds. One male supplanted a Rufous-throated Antbird, but two females were chased by the latter. No other disputes were recorded; these birds generally avoid the fights directly over the ants.

Scale-backed Antbird (Hylophylax p. poecilonota). - Fairly common ant-follower at Serra do Navio; otherwise not noted often.

At Serra do Navio they perched mainly on thin vertical or diagonal branches, about $1 \mathrm{~m}$ up. In many other regions, Willis has found it clinging near swarms on thick perches and 1-2 mi up whenever competitors exclude it from the best central zones over the ants; it moves to low slender perches over the ants when competitors are absent.

Like other antbirds, Scale-backed Antbirds usually sally briefly to the ground to get prey. At times one perched near the ground or a bit of vegetation just sticks out the head and neck to peck prey from it. Sometimes one chases prey to the ground and tosses leaves for some time looking for it. Prey included cockroaches and other small insects, one to one and a half times the exposed bill length ( $I B=13 \mathrm{~mm}$ ).

\section{NONPROFESSIONAL ANT-FOLLOWERS}

\section{TINAMOUS (Tinamidae)}

Great Tinamou, Tinamus major. - One quickly deserted the first antswarm encountered at Nappi. In other regions, this tinamou occasionally picks up insects as it walks around the outskirts of raids, but is so timid it is nearly impossible to watch.

\section{FALCONS (Falconidae)}

Barred Forest-Falcon, Micratur ruficollis. As in the undergrowth of other areas of secondary woodland and forest edges in Amazonia, this small hawk occasionally terrified other antfollowing birds at Nappi by darting past or by flying to a perch $2-5 \mathrm{~m}$ above the ants and waiting. The other birds stayed behind cover or $10 \mathrm{~m}$ away, except for an occasional sleeked Black-banded Woodcreeper, while the hawk flew to the ground now and then to capture large spiders and other arthropods. One stood in the midst of ants, a katydid in its talons, and killed it with several bites. It is a persistent antfollower if the observer does not chase it away.

\section{TRUMPETERS (Psophiidae)}

Gray-winged Trumpeter, Psophia crepitans.At Nappi, small bands of two to eight clanking and grunting trumpeters sometimes stalked around army ants like short-legged cranes, picking up a fleeing arthropod here and there. They worked mainly behind dense undergrowth when the observer was very quiet, and flew up to overhead limbs or ran away as soon as he moved.

\section{cuckoos (Cuculidae)}

Squirrel Cuckoo, Piaya cayana. — In second growth near the road at Serra do Navio, one briefly came down from the canopy and looked around a swarm from $2 \mathrm{~m}$ up. In other regions, Squirrel Cuckoos occasionally follow army ants by coming down from the canopy to low tangles of lianas.

\section{MOTMOTS (Momotidae)}

Blue-crowned Motmot, Momotus momota. - At all sites but Serra do Navio, one or two birds occasionally waited on thick horizontal branches $1.5 \mathrm{~m}$ above the ants. In this and other regions, these motmots follow army ants persistently unless the observer scares them off, but generally do so only when ants are near the gullies or patches of woodland where they have home ranges.

\section{PUFFBIRDS (Bucconidae)}

Black Numbird, Monasa atra. - At the edges of clearings at Nappi, small groups or single birds occasionally joined groups of woodcreepers when the ants flushed prey in tangles of lianas 7 to $15 \mathrm{~m}$ above the ground. These nunbirds, like many other puffbirds, wait on horizontal perches and sally to trunks and foliage for large insects.

\section{WOODCREEPERS (Dendrocolaptidae)}

Spot-throated Woodcreeper, Deconychura stictolaema. - One was foraging on vertical 
thin trunks $1.5 \mathrm{~m}$ over the ants in forest at Serra do Navio, May 9; it was later collected.

Wedge-billed Woodcreeper, Glyphorhynchus spirurus. - Infrequently these small, forestinhabiting woodcreepers, which often join wandering flocks, stayed around a swarm of ants for several minutes at Serra do Navio, Nappi, and Bartica. They perch on slender to large vertical trunks, usually $1-5 \mathrm{~m}$ up but sometimes as high as $25 \mathrm{~m}$, and hitch upward looking and pecking at the edges of patches of lichens or bark in the usual fashion rather than catching insects flushed by the ants, except on rare occasions. They seem to react more to the birds, as a substitute for a wandering flock, than to the foraging opportunities around ants.

Buff-throated Woodcreeper, Xiphorhynchus g. guttatus. - At Nappi, one to two birds regularly followed several swarms of ants near the edges of forests. Usually they peck out insects while hitching up vertical trunks and peering closely at crevices and epiphytes or prying off flakes of bark; ones with ants vary the routine by sallying to foliage or into the air occasionally. They seem to join active groups of ant-following birds rather than follow ants on their own; away from ants, they often join wandering flocks. They chase or fight with other woodcreepers readily, even the large Black-banded Woodcreepers and Barred Woodcreepers, but generally stayed above the zone of high competition near the ground.

Chestnut-rumped Woodcreeper, Xiphorhynchus pardalotus. - At all locations except Bartica, one or two birds occasionally left wandering flocks in the forest and for short periods hitched up or down vertical trunks 1 to $15 \mathrm{~m}$ above the ground near the army ants, peering or hammering into crevices and cavities or into the crowns of palms. At times one went to the ground for prey or sallied to foliage near the trunk.

\section{ANTBIRDS (Formicariidae)}

Fasciated Antshrike, Cymbilaimus lineatus. - Two briefly left a wandering flock at the forest edge at Nappi and joined birds at a swarm of ants. There, as in other regions, these antshrikes stay $2-15 \mathrm{~m}$ up in dense vine-covered small trees or at the edge of the forest and follow ants only when they are passing by.

Great Antshrike, Taraba major. - One left the same wandering flock and briefly followed the ants. In most regions these antshrikes follow ants only when they go through dense second growth or riverside tangles; but on Trinidad, where there are few protessional antfollowers, the antshrikes regularly follow ants deep into nearby forests.

Mouse-colored Antshrike, Thamnophilus murinus. - At Serra do Navio, from 10:06 to 11:05 on May 14, a pair followed ants in deep forest. They perched on horizontal (rarely vertical) thin branches 1-8 $\mathrm{m}$ up, wandering down to near the ants at times. Once the female hopped on the ground to get prey. Normally these birds forage 3 to $15 \mathrm{~m}$ up in the forest undergrowth with wandering flocks and do not follow ants.

Slaty Antshrike, Thamnophilus p. punctatus. - At the edge of the forest at Nappi, a female briefly left a wandering flock and foraged $4 \mathrm{~m}$ up in lianas, pecking small prey here and there. Normally birds of Amazonian races of this species are restricted to second growth and forest edges and do not follow ants persistently.

Cinereous Antshrike, Thamnomanes caesius. - Occasionally at Serra do Navio and Nappi individuals or pairs of this flycatcherlike species left their normal stations in wandering flocks and foraged over the ants for a few minutes, especially when flocks foraged near the ants. They usually sit rather vertically on horizontal slender perches 3 to $10 \mathrm{~m}$ above the ground, but move lower when near ants. They look about and sally quickly to the air or foliage, rarely to the ground; often one returns to the same branch after a sally. Prey are mainly such insects as grasshoppers, up to one or two times the beak length.

Dusky-throated Antshrike, Thamnomanes ardesiacus. - Another flycatching antbird of wandering flocks, one that contrary to Snyder (1966) usually works nearer the ground (1-5 m) than the very similar preceding species. Individuals and pairs at Nappi occasionally joined ant-following birds while or up to an hour or so after a wandering flock passed by. They 
sally up to a few meters to foliage or into the air for arthropods up to twice the length of the bill.

Rufous-bellied Antwren, Myrmotherula guttata. - Plump, short-tailed wrenlike antbirds that, like the closely related Plain-throated Antwren ( $M$. liauxwelh) seem more like members of the genus Hylophylax than like other members of the genus Myrmotherula. Pairs wander pecking and hovering through slender sprouts and saplings near the ground in the forest interior, often with wandering flocks. Twice at Serra do Navio and once at Nappi, pairs followed swarms of ants irregularly for several hours, keeping mostly at the periphery of the raids.

White-flanked Antwren, Myrmotherula axiilaris. - At Nappi, one or two left a wandering flock to follow ants briefly at the forest edge. Normally they forage with flocks in foliage in the lower midlevels of the forest. Haverschmidt (1968) records it as an ant-follower, but it does not follow ants as often as do the other species he records as ant-followers.

White-browed Antbird, Myrmoborus leucophrys. - A persistent ant-follower on some days at Nappi, especially when ants passed through dense undergrowth at forest edges and in second growth. On other days, they either joined wandering flocks or foraged away from other birds and ants. Pairs hop on the ground or on low horizontal to vertical perches, sometimes waiting patiently several seconds and peering about before fluttering short distances after insects or to peck them off They seem to have difficulty sallying to catch prey on the ground among ants, for they normally fly in the midst of ants and peck the prey there rather than carrying it back to a perch. Occasionally one moves 3 or $4 \mathrm{~m}$ up in tangles of lianas or fallen trees.

Warbling Antbird, Hypocnemis cantator. At Serra do Navio and Nappi, pairs or single birds sometimes followed wandering flocks or army ants irregularly for several hours, especialy when the flocks or ants were in second growth or at the edge of the forest. These small birds perch mainly on slender twigs and stems from 0 to $2.5 \mathrm{~m}$ up in dense vegetation. They wander and look about in foliage like gnatwrens
(Ramphocaenus and Microbates spp.) and peck or sally to overhead leaves for small prey.

White-bellied Antbird, Myrmeciza longipes. - At Nappi, pairs or single birds occasionally followed ants for long periods when they were in dense growth or near the edges of the forest. As in other regions, these birds hopped near the ground or on it and pecked prey on the ground or low foliage.

Ferruginous-backed Antbird, Myrmeciza ferruginea. - At Nappi, pairs walked on the ground around swarms of ants for a few minutes, pecking at the leaf litter or at branches on treefalls; much of the time they ignored ants.

Spot-backed Antbird, Hylophylax naevia. At Serra do Navio, lone birds or pairs visited several army ant swarms, feeding on small insects near the ground or on fallen logs. They perch near the ground on vertical or diagonal thin branches much of the time.

Black-faced Antthrush, Formicarius analis. - At Nappi, lone birds or pairs occasionally walked around swarms of ants like rails or bantam chickens, and pecked at the ground or tossed a leaf aside here and there. At one swarm one walked near a bird of the following species, which gave way; usually they did not react to each other.

Rufous-capped Antthrush, Formicarius colma. - At Nappi and Reserva Ducke, lone birds or pairs occasionally walked around swarms of ants and pecked prey here and there much as does the Black-faced Antthrush.

Chestnut-belted Gnateater, Conopophaga aurita. - At Serra do Navio antswarms, quiet lone birds or pairs occasionally waited hunched up on thin branches less than a meter up. They capture such small insects as beetles by flying to the ground in the middle of the ants or to foliage near the ground.

\section{COTINGAS (Cotingidae)}

Bright-rumped Attila, Attila spadiceus. - At Nappi, pairs often joined woodcreepers in sallying for prey in overhead liana tangles. They normally perch on horizontal twigs 2 or $3 \mathrm{~cm}$ in diameter, at 1 to $10 \mathrm{~m}$ above the ground (especially above $3 \mathrm{~m}$ ), and sally like flycatchers 
to nearby foliage. They reverse, hop a few centimeters, wag the tail up and down, and soon move on. One was supplanted by a Plainbrown Woodcreeper.

Capuchinbird, Perissocephalus tricolor. At Serra do Navio, one was 12 to $15 \mathrm{~m}$ up over a swarm for some 30 minutes, and ate one prey.

\section{GUIANAN COCKS-OF-THE-ROCK (Rupicolidae)}

Guianan Cock-of-the-Rock, Rupicola rupicola. - At Nappi, one brilliant male volplaned down to $7 \mathrm{~m}$ above the ants in the forest and looked down at them, but fled when it saw the observer. A female briefly joined a group of woodcreepers feeding high above the ants on one other occasion. This and the preceding species probably are generally fruit eaters and pay little attention to ants.

\section{MANAKINS (Pipridae)}

Golden-headed Manakin, Pipra erythrocephala. - At Serra do Navio, one female briefly visited $2 \mathrm{~m}$ over a forest swarm, but departed after a White-plumed Antbird flew nearby.

White-crowned Manakin, Pipra pipra. Several times birds in female plumage (rarely males) foraged over ants in patchy second growth at Serra do Navio and at Nappi. They perched mainly on thin horizontal and diagonal branches 1-3 $\mathrm{m}$ up, rarely as much as $8 \mathrm{~m}$. In foraging, a bird waits and searches foliage: above it, then flies to a new perch or to hover and capture an insect in the air or on the foliage

White-fronted Manakin, Pipra serena. - One female briefly foraged at $0.5 \mathrm{~m}$ above ants in forest at Reserva Ducke, then fled. Like most other small manakins, this species and the related Blue-crowned Manakin, Pipra coronata, occasionally follow ants in most regions; femaleplumaged birds follow far more often than do adult males.

White-bearded Manakin, Manacus manacus. - At Serra do Navio, a few were briefly around swarms in second growth along a road, staying low (2-4 $\mathrm{m}$ up) as usual.

Tiny Tyrant-Manakin, Tyranneutes virescens. - Once at Nappi a displaying bird hovered below a leaf $4 \mathrm{~m}$ up and snapped up a few tiny flying insects flushed by ants. Normally these manakins display separately $2-15 \mathrm{~m}$ up in woodland and ignore ants.

\section{TYRANT FLYCATCHERS (Tyrannidae)}

Ringed Antpipit, Corythopis torquata. - At Nappi, paired or lone antpipits sometimes walked on the ground or fallen branches around swarms, bobbing their heads back and forth like pigeons. They pecked here and there and made sudden runs or leaps in to the air for escaping tiny insects. They behave similarly when away from ants. In classification, we follow Heimerdinger and Ames (1967), who suggest that the antpipits are aberrant tyrant flycatchers and that gnateaters are antbirds, but think that both these unusual groups need more study.

Sulfur-rumped Flycatcher, Myiobius barbatus?. - One in second growth at Serra do Navio foraged briefly at 4 to $7 \mathrm{~m}$ over ants, moving actively with tail spread, as a wandering flock passed by. Normally these birds stay with wandering flocks and ignore ants.

Pipromorpha sp. - At Nappi, one snapped up an insect over ants as a wandering flock passed in vine-covered second growth along a forest edge. In general tyrant flycatchers ignore ants.

\section{WRENS (Troglodytidae)}

White-breasted Wood-Wren, Henicorhina leucosticta. - Occasionally at Serra do Navio and Nappi one to three birds wandered in low undergrowth around swarms of ants for long periods. The perches are mostly slender vertical or horizontal ones, occasionally the ground or logs; flights between perches were generally less than $4 \mathrm{~m}$. The wrens forage rapidly, hopping quickly from twig to twig or on the ground. They often take small insects by lunging to peck the ground, fallen logs, or low foliage. At times they peer under fallen leaves.

\section{THRUSHES (Turdidae)}

Cocoa Thrush, Turdus fumigatus. - At forest edges at Nappi, a few individuals hopped on the ground or logs near the ants and 
waited like Robins (Turdus migratorius) after earthworms; one tossed fallen leaves. They flicked wings and tails on flying up to high perches, then deserted, when the observer came near.

White-necked Thrush, Turdus albicollis. In forests at Nappi and Serra do Navio, occasional individuals hopped on the ground or logs near ants but flew up to high perches and deserted quickly when we approached. Attempts at prey included fluttery sallies to the ground, a peck at the ground, and a sally to snap insects off limbs to $10 \mathrm{~m}$ up. One ate a berry near ants. Neither thrush is as frequent at swarms in this region as on Trinidad, where antfollowing antbirds are almost absent.

\section{WARBLERS (Sylviidae)}

Collared Gnatwren, Microbates collaris. - Near a swarm at Reserva Ducke, one persistently wandered through low sprouts at 0.2 to $0.7 \mathrm{~m}$ up for half an hour It sallied to the ground and pecked at low foliage, taking the niche of a Warbling Antbird.

\section{WOOD WARBLERS (Parulidae)}

River Warbler, Basileuterus rivularis. - On several occasions, pairs and individuals followed army ants for long periods near streams and forest edges at Serra do Navio and Nappi. They hop, pounding or slightly wagging olive-yellow spread tails, on the ground and low horizontal and diagonal thin branches as much as $1.5 \mathrm{~m}$ up and fly off rapidly now and then only to return later. They pivot back and forth, looking actively and emphasizing each pivot with a sideflick of the tail. Much of the tiny prey is pecked from the ground or low vegetation, but some is captured by flycatching vertical or diagonal sallies of 20 to $80 \mathrm{~cm}$ into the air or to leaves. We both saw them eating small moths.

\section{TANAGERS (Thraupidae)}

Silver-beaked Tanager, Ramphocelus carbo. - Twice at Serra do Navio, in irregular forest and second growth, individuals visited but fled on seeing the observer. At Belém, Oniki has found them with ants in second growth relatively often.

Fulvous-crested Tanager, Tachyphonus surinamus. - One male at Serra do Navio came down near ants briefly when a wandering flock passed by; normally they are in wandering Hlocks or separate and ignore ants.

\section{FINCHES (Fringillidae)}

Pectoral Sparrow, Arremon taciturnus. A few times one hopped on the ground near army ants in dense undergrowth at the forest edges at Nappi; occasional ant-following when ants pass through such habitats has been noted in other parts of Amazonia.

\section{NUMBERS OF BIRDS AT SWARMS}

Table 2 lists the average numbers of birds attending swarms of Eciton burchelli on the four study areas. The numbers are approximate, for it is difficult to determine how many birds are following a given swarm if there are many birds present or if some are timid.

Rufous-throated Antbirds and White-plumed Antbirds are the most numerous birds, followed except at Reserva Ducke by Plain-brown Woodcreepers and Black-headed Antbirds. At Serra do Navio Scale-backed Antbirds were regular ant-followers, but they were rare or absent elsewhere. The two species of Dendrocolaptes were uncommon at Serra do Navio, moderately crmmon at Nappi. Red-billed Woodcreepers were rare everywhere.

Nonprofessional species were most numerous at Nappi, where Bright-rumped Attilas and White-browed Antbirds followed persistently, as did birds of several other species. Flocks of trumpeters and nunbirds visited briefly, giving high totals, but did not stay long. At Serra do Navio, the main nonprofessional species were White-crowned Manakins and White-breasted Wood-Wrens.

Nonprofessional species, in general, stay with the ants less persistently than to professional ones. Therefore, a simple list of numbers of birds visiting overemphasizes the 
role of nonprofessional species. It is very difficult to keep track of many individuals and determine how long each one stays, but approximate data of this type are available for Nappi (Table 1, in parentheses). By this measure. nonprofessionals form only 17.1 percent of the birds present while by the "list" method they form 35.8 percent. Another measure of persistence is tabulating all field-note records, one by one, for each species. A third method, which also depends on our taking records randomly, is to tabulate all records of prey captures. Ailthough a few birds hide so well that they are not recorded enough, and there was some tendency for us to watch certain species rather than others (especially Plain-brown Wood. creepers at Nappi and Bartica), our records of occurrence and of prey captures still give a rough idea of how much different species use the ant swarms. Such data are given in Table 3. All data, of course, are influenced by the presence of the observer; shy species like Redbilled Woodcrepers are underrecorded with respect to tame ones like Warbling Antbirds

\section{CONSTANCY OF ANT FOLLOWING}

Johnson (1954) notes that in Panamá some ant-following birds were at swarms day after day while others were not so regular. He interpreted this to mean that the former were not so territorial or restricted to habitat as the latter. However, if a nonterritorial species or unrestricted one is wary of the observer or rare it can also be irregular at a given colony of ants. Regularity of following can also occur in a territorial species if it is common or has overlapping foraging ranges, or in a species of limited habitat if the ants happen to stay in that habitat. For these reasons, Johnson's estimates of territoriality and restriction to habitat for Panamanian ant-followers are often incorrect (Willis, 1967). Regularity of following seems to be more often correlated with professional antfollowing than with degree of territoriality or habitat restrijction.

In the region north of the eastern Amazon, a professional ant-following bird or its conspecific replacement was more likely than a nonprofessional one or its replacement to be rediscovered at a colony of ants the day following each census. At Serra do Navio the ratio of repeats/disappearances when a given colony of ants was visited the next day was 44 individuals/31 for professionals and 13/29 for nonprofessionals; at Nappi, the ratios were higher but comparable, 165/42 for professionals and $62 / 68$ for nonprofessionals. In both areas, therefore, one was three or four times as likely to rediscover a professional ant-follower or its conspecific replacement at a swarm the next day as to find a nonprofessional one or its replacement.

While some professional ant-followers (Barred, Black-banded, and Red-billed Woodcreepers at Serra do Navio, Red-billed Woodcreepers and Scale-backed Antbirds at Nappi) were locally tare and occurred only at one to four swarms of Eciton burchelli, the other professional ant-followers were at 11 to 18 of the 29 swarins at Serra do Navio and 15 to 19 of the 19 swarms at Nappi (Table 3). Most nonprofessional species were common ones repeatedly noted away from swarms of ants, while most professional ones were seldom seen away from ants.

\section{Changes IN NUMBers \\ AND PREY CAPTURES DURING THE DAY}

Table 5 shows the average numbers of records of birds for different hours of the day at Serra do Navio and Nappi. There are few birds active until the sun reaches the dark lower levels of the forest and the ants build up an active swarm, about $07: 30$. There is high bird activity to $13: 00$ and moderately high activity to 16:00; then the ants are in retreat or are starting a move to a new bivouac. Using observations per hour in Table 5 rather than dividing observations by the total number of days flattens the daily rise, of course, because we commonly went only to the most active colonies early or late in the day. We thus avoided the very lowest records early in the morning or late in the ofternoon.

Table 5 also shows the average numbers of records for professional ant-followers at Serra do Navio and Nappi at different hours of the day. At both places, White-plumed Antbirds 
tend to attend swarms later in the day than do Rufous-throated Antbirds, perhaps because the latter chase them during active morning foraging. Black-headed Antbirds are most active very early in the morning and late in the afternoon, perhaps because Rufous-throated and White-plumed Antbirds outcompete them during the rest of the day. Red-billed, Black-banded, and Barred Woodcreepers tend to be active from 09:00 to 15:00. Part of the time they work trees, which ants climb mainly at midday after starting on the ground and before returning to it for bivouac changes late in the day. There is also more light on the forest floor at midday, and the small-eyed woodcrepers tend to be less birds of the deep shade than are the large-eyed antbirds. Perhaps this is why the woodcreepers tend to catch prey nearer the ground at midday (Fig. 2). Present-day competition with antbirds is not likely to be the reason, except perhaps morning competition between Plain-brown Woodcreepers and the Rufous-throated Antbirds (Willis, 1966). The woodcreepers are nearly all bigger than the antbirds and should be able to displace the latter at any hour of the day.

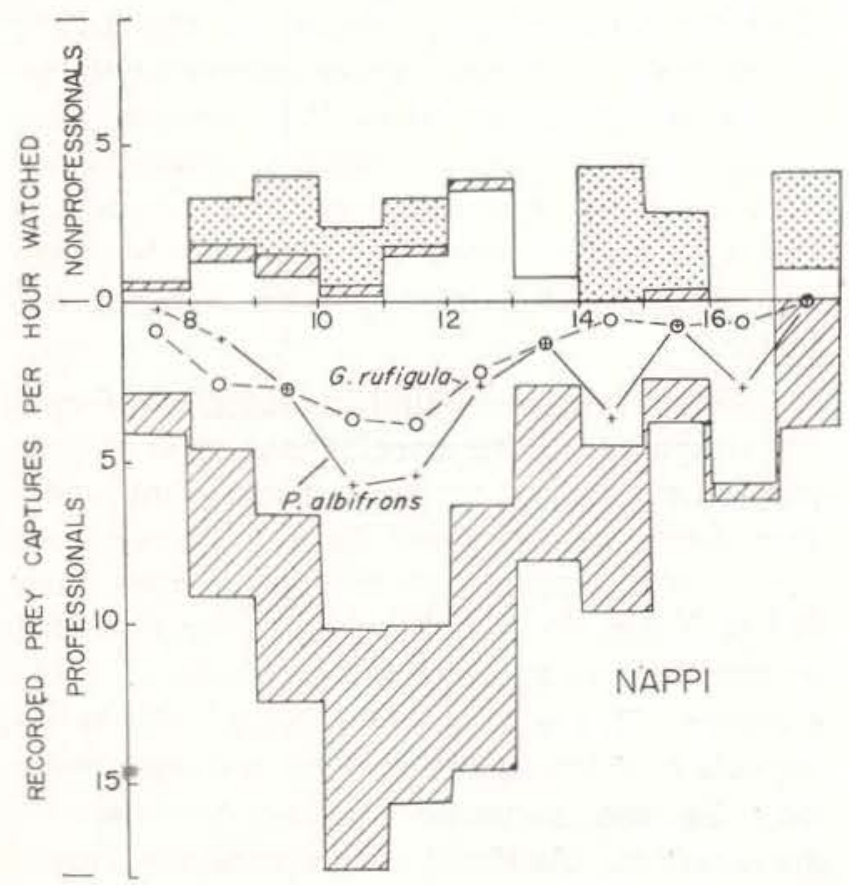

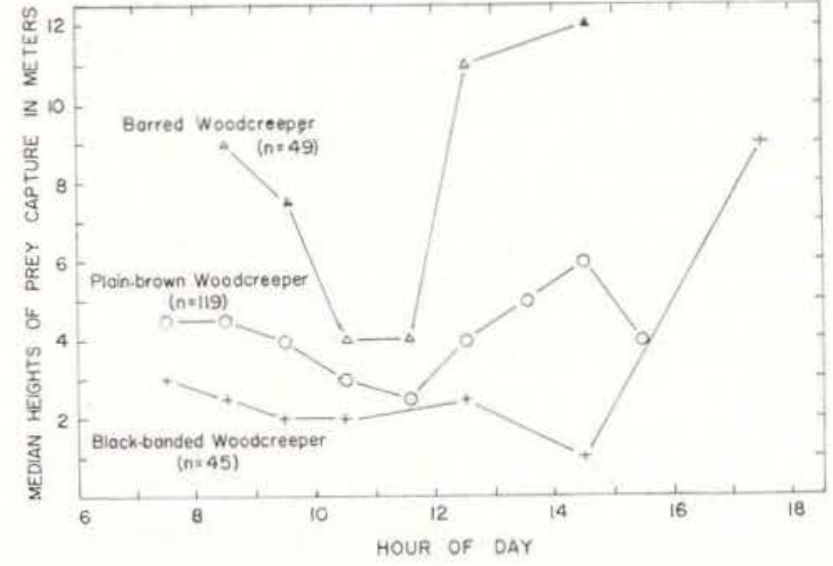

Fig. 2 - Median heights of prey capture for three species of woodcreepers at different hours of the day, at Nappi.

Figure 3 shows numbers of captures per hour at different hours of the day at Serra do Navio and Nappi. At both places professional antbirds increase rapidly, followed by nonprofessional antbirds to about 09:00. The prey captures of nonprofessional antbirds decline as captures by professional ones rise to a broad peak between 09:00 and 13:00. As activity by professional antbirds declines at noon there is

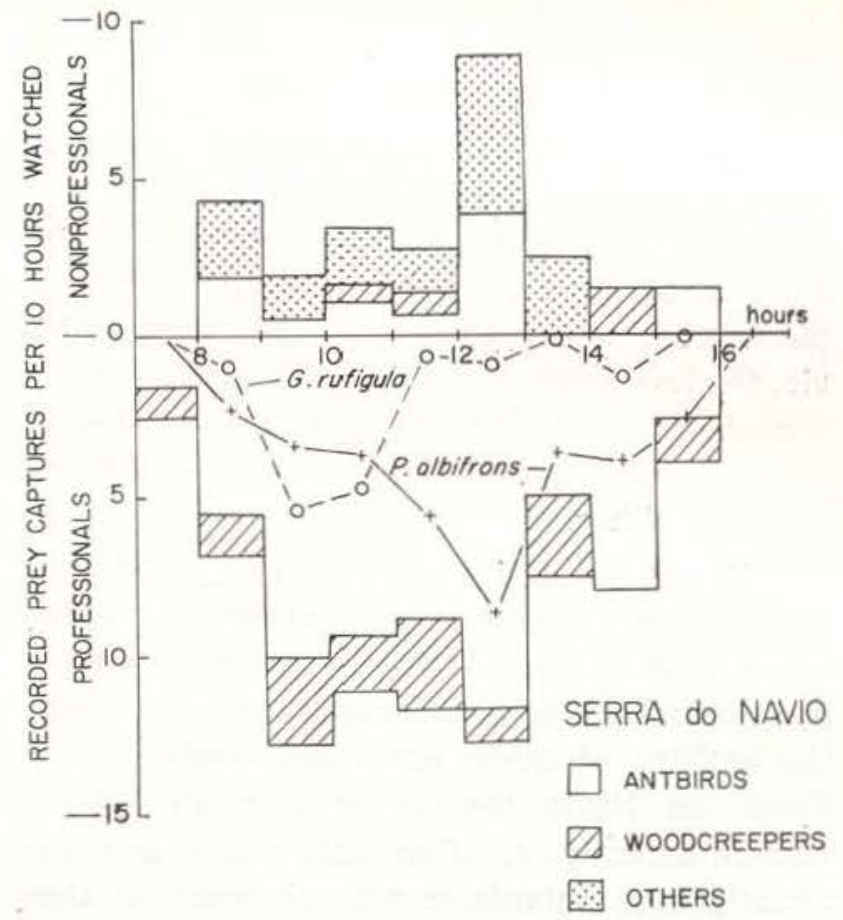

Fig. 3 - Recorded prey captures per hour or 10 hours watched at different hours of the day; nonprofessional species above, professional ones below. 
a midday resurgence of activity by the nonprofessional antbirds, which thus tend to bracket the morning activity of the professional ones. Activity of nonprofessional antbirds declines with the midafternoon peak in activity of professional ones, but rises slightly again late in the day. Probably most antbirds have gathered most of their food for the day by that time.

The first lagging and then alternating relationships between professional and nonprofessional antbirds during the day appear at both Serra do Navio and Nappi, and confirm our general impression that the nonprofessional antbirds tend to move peripherally or leave when the professional ones become most active The pattern from Serra do Navio is somewhat obscured by a strong midday peak in activity of the subordinate White-plumed Antbird, which may be usurping the roles of nonprofessionals here because of its abundance and because of the strongly excluding midmorning activity of the dominant Rufous-throated Antbirds. A similar relationship of morning activity in $G$. rufigula and midday activity in $P$. albifrons is somewhat evident at Nappi, but the activity records of the two (Table 5) show this pattern more clearly there than do the prey-capture records. Possibly the two species compete less at Nappi than at Serra do Navio.

Nonprofessional woodcreepers tend to capture food mainly in the morning at Nappi, where professional woodcreepers are active from $08: 00$ to $18: 00$ and perhaps gradually outcompete them each day. At Serra do Navio, the low levels of professional woodcreepers probably do not offer serious competition to nonprofessional ones, but the latter are not common either.

Nonprofessionals other than antbirds and woodcreepers tend to move in at the most active times of morning. At Nappi the noon peak in nonprofessional antbird foraging seems to break the activity of other nonprofessionals, but at Serra do Navio the latter just add to the noontime activity. Few of them compete directly with antbirds or woodcreepers, so they probably move in mainly when birds are active and food is superabundant.

\section{ForAGING COMPETITION}

In all areas, most of the prey are captured near the ground. Antbirds capture most of the prey near the ground, woodcreepers most of the prey high above the ground (Figs. 4,5). At Serra do Navio, antbirds captured 68 percent $(102 / 150)$ of the total prey and woodcrepers 16 percent $(24 / 150)$; antbirds took 51 percent and woodcrepers 37 percent at Nappi $(n=661)$; at Reserva Ducke antbirds took 55 percent and woodcreeprs 38 percent $(n=53)$; at Bartica antbirds took 85 percent and woodcrepers 15 percent $(n=13)$.

Rufous-throated and White-plumed Antbirds capture most of the prey at ground level, with the assistance of Black-headed Antbirds and Scale-backed Antbirds (Fig. 4). These four, especially the third, take lesser amounts of prey up to $3 \mathrm{~m}$ above the ground. At this level Black-banded Woodcreepers become the most important predators; even though the species gets more of its prey on the ground than at $3 \mathrm{~m}$ up it is not taking many of the very numerous prey items at low levels compared to the antbirds. At Nappi the Plain-brown Woodcreeper takes a high percentage of the available prey at 2 and at 4 to $7 \mathrm{~m}$ up; perhaps the larger Black-banded Woodcreepers tend to exclude it from the 3-meter level. Above $7 \mathrm{~m}$ the field is dominated by Barred Woodcreepers at Nappi. In places where Red-billed Woodcreepers are common they tend to replace Black-banded Woodcreepers and even antbirds at ground levels, but they were not common or tame enough in the study areas to be a significant factor.

Nonprofessional antbirds (especially Formicarius spp.) and other species take most of their prey on the ground but are not important predators there; at Nappi and Serra do Navio they are relatively more important in the zone from 0.1 to $3.0 \mathrm{~m}$ up, in betwen the zones occupied by professional antbirds and professional woodcreepers. This is a zone of vertical leafy stems, especially at the forest borders, and sometimes may be too cluttered for woodcreepers to maneuver in. At Nappi several antbirds, primarily the flycatching Thamnomanes caesius and $T$. ardesiacus, sometimes moved in at 3 to $5 \mathrm{~m}$ up. 


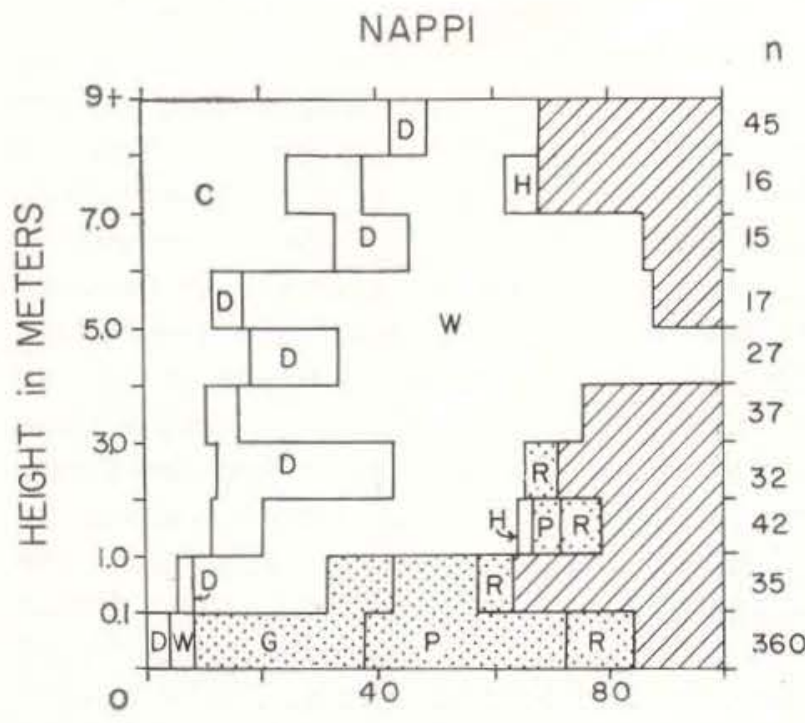

PER CENT of $n$ (PREY ATTEMPTS)

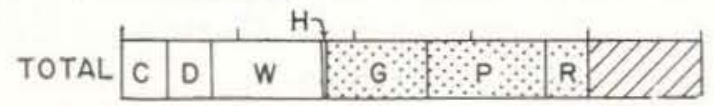

PROFESSIONAL WOODCREEPERS

$C$-Dendrocolaptes certhia

D-Dendrocolaptes picumnus

$W$-Dendrocincla fuliginosa

$\mathrm{H}$-Hylexetastes perrotti

PROFESSIONAL ANTBIRDS

G-Gymnopithys rufigula

$\mathrm{P}$-Pithys albifrons

$\mathrm{R}$-Percnostola rufifrons

Hp-Hylophylax poecilonota

DI NONPROFESSIONALS

SERRA do NAVIO

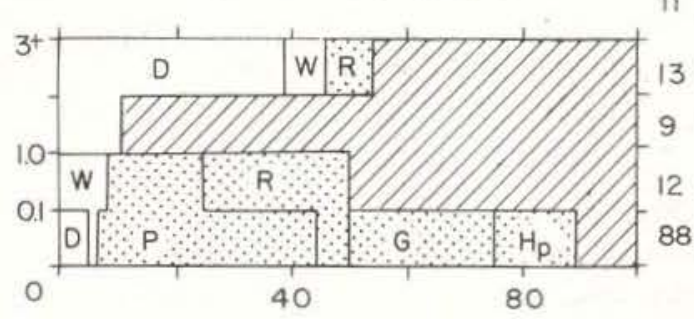

PER CENT of $n$ (PREY ATTEMPTS)

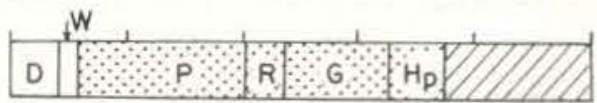
122

Fig. 4 - Prey captures at different heights $n=$ number of captures at each height

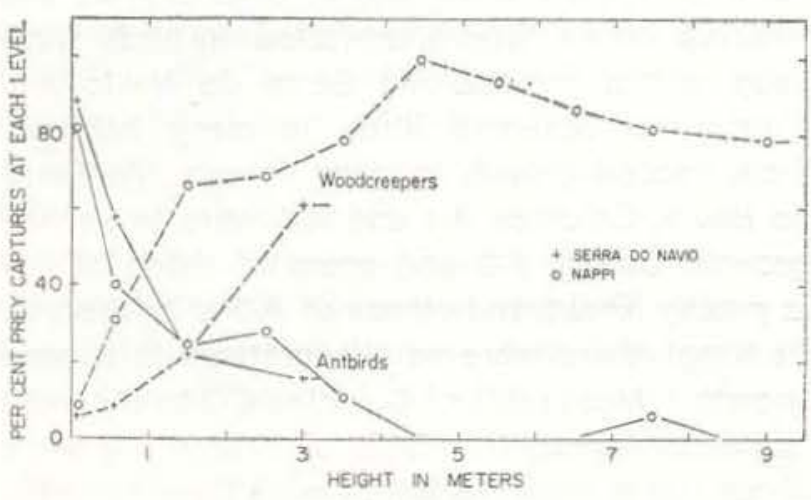

Fig. $5-$ Percentages of total prey taken by woodcreepers and antbirds at each height.

However, the numerous antwrens (Myrmotherula spp.) and antshrikes (Thamnophilus spp.) of these middle zones usually leave these zones to woodcreepers over the ants.

Above $8 \mathrm{~m}$ the antbirds are almost absent over ants, and other kinds of nonprofessional birds supplement professional woodcreepers in taking rather scanty but often large prey: Black
Nunbirds, Buff-throated Woodcrepers, and a scattering of other species.

\section{HEIGHTS, ANGLES, AND DIAMETERS OF PERCHES}

Appendices 1, 2 and 3 list the heights, angles, and diameters of perches recorded for various species at Serra do Navio and Nappi. The data from Serra do Navio include al! records, including records of food captures and of perches where birds were preening or doing other activities. The data from Nappi include only perches on which the bird seemed to be foraging, and exclude places of food capture plus alarmed or disputing or preening or traveling birds. The main difference between the two types of presentation is that records from Serra do Navio include many prey-capture records on or near the ground.

White-plumed Antbirds tend to use perches that are vertical rather than horizontal, under $1.0 \mathrm{~cm}$ in diameter, and 0.4 rather than $0.3 \mathrm{~m}$ above the ground more often than do Rufous- 
throated Antbirds. Black-headed Antbirds tend to perch on the ground or near it $(0.1$ or $0.2 \mathrm{~m})$ and up to $3 \mathrm{~m}$ above the ground more than do the above two antbirds, but are like them in diameters and angles of perches. Scale-backed Antbirds tend to use high perches ( 1 to $2 \mathrm{~m}$ up) more and horizontal perches less than do the other professional antbirds. Nonprofessional aritbirds vary from walking on the ground around the outskirts of swarms through using variable heights like Black-headed Antbirds to using zones 1 to $3 \mathrm{~m}$ up. Species that compete fairly directly with the professional antbirds are Hylophylax naevia, Conopophaga aurita. Myrmoborus leucophrys, and Myrmeciza longipes. The first two seldom follow ants and the last two tend to be in swamps or second growth where professional ant-followers are uncommon.

The antbirds all use slender perches and stay relatively near the ground. Many move easily from vertical to horizontal perches. Woodcreepers, by contrast, usually stay on vertical trunks above the ground. However, they are more adaptable in foraging height than are antbirds. Barred Woodcreepers in this region seldom perch below one meter up, but Plain-brown and Black-banded Woodcreepers regularly do so. They are hindered from perching below $0.2 \mathrm{~m}$ because their long tails project down, and perhaps also because they reed room to do a $180^{\circ}$ turn in order to go to the ground for food. The horizontal-clinging antbirds can be close to the ground over the ants and need not turn $180^{\circ}$ each time they drop to the ants for food.

Plain-brown Woodcreepers commonly use trunks of 4 to $15 \mathrm{~cm}$ in diameter, but can use diameters down to about $1 \mathrm{~cm}$ by putting one foot above the other and using only the central tail feathers. They also use large trunks, and hence are very flexible in use of different perch diameters. Barred Woodcreepers seldom use siender perches, and favor medium-sized trunks. Black-banded Woodcreepers are intermediate between the other two-species.

None of the woodcreepers, except perhaps the nonprofessional Buff-throated Woodcreeper, use perches near the horizontal very often. The nonprofessional woodcreepers seldom catch prey flushed by ants, but sometimes stay with ant-following birds persistently as if socially attracted.

Some of the other nonprofessionals (River Warbier, Ringed Antpipit) walk or hop on or near the ground around swarms and thus do not compete with professionals directly over the ants. None use vertical perches as well as do most professionals, and hence the nonprofessionals seldom stay on trunks over the ants. White-breasted Wood-Wrens and Whitecrowned Manakins tend to forage above the zones of professional antbirds and below those of professional woodcreepers. Nonprofessionals that occupy the same height ranges as professionals are otherwise uncommon antfollowers, except for the high-foraging, forestedge Black Nunbirds and a vine-tangle "flycatcher", the Bright-rumped Attila. The latter uses horizontal perches in vine tangles and competes directly with Plain-brown Woodcreepers at times, but is restricted to forest-edge and second growth in most areas.

\section{SECOND GROWTH AND FOREST BORDERS}

The percentages of nonprofessionals attending swarms were low at both Bartica and Reserva Ducke, where ant-following birds were deep within forests. At Serra do Navio and Nappi, we observed birds in many habitats, from second growth to deep forest. At Serra do Navio, Colonies $A-1$ and $A-4$ were in second growth, Colony A-2 and some of those of A-3 in patchy forest, and others of A-3 in tall forest. At Nappi, there were no observations in second growth. Most raids of Colonies C-2 to C-4 were in patchy forest, two raids of Colony C-2 were about $100 \mathrm{~m}$ from the forest edge ("near edge"), and all raids of Colony $\mathrm{C}-1$ were inside extensive forest but near Nappi Creek.

At both Serra do Navio and Nappi, the percentages of professionals at swarms became higher as one went from second growth into forest edge and then deeper into forest areas (Fig. 6). Percentages of professional antbirds iricrease into forest in both areas, but percentages of professional woodcreepers were about the same (18 percent in forest and edge, 27 percent near edges) at Nappi and low (6 percent) except in forest (20 percent) at Serra do Navio. 


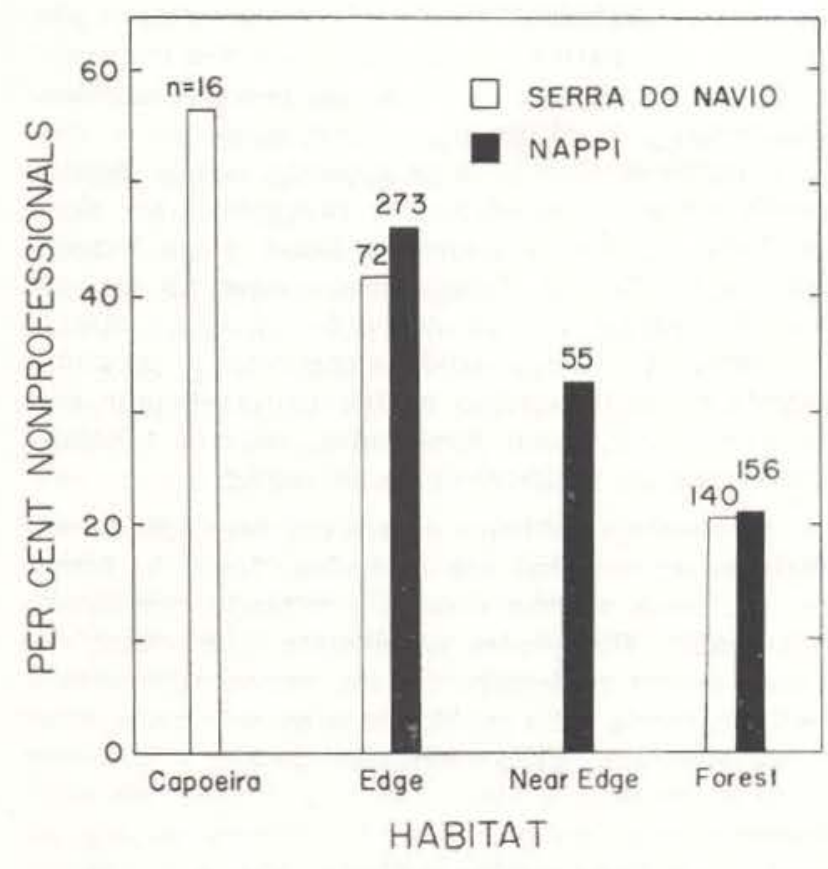

Fig. 6 - Percentages of nonprofessional ant-follower in successively more mature forests.

\section{COMPARISON WITH OTHER}

\section{ANT-FOLLOWING GUILDS}

A comparison between the guild of antfoilowing birds in the region north of the easiern Amazon (the "Amapá" guild) and the guild Johnson (1954) reported following the same ants in Panamá shows some similarities and many differences. In both the Amapá and Panamá guilds, the woodcreepers Dendrocolaptes certhia and Dendrocincla fuliginosa perform similar roles, although the former visits the ground more often in Panamá. The antbird Gymnopithys rufigula replaces the perhaps conspecific Gymnopithys bicolor of Panamá.

There are no large antbirds that could correspond to the Phaenostictus mcleannani of Panama. The small Hylophylax naevioides of Panamá, which with 50 percent of its prey over ants is barely a professional, is replaced in part in Amapá by the completely professional and much more numerous Pithys albifrons and in part by the professional but local Hylophylax poecilonota, ammore specialized member of the genus Hylophylax naevia, which is very close to $H$. naevioides, is apparently not a threat to the professional ant-followers; it occurs with ants in Amazonia mainly when there is little compe- tition. There is a fourth species of antbird north of the eastern Amazon, the medium-sized Percnostola rufifrons, which as a second-growth professional has no direct counterpart in Panamá. It may replace to some extent the tanager Eucometis penicillata, which is local in the Amapá region. Thus Panamá has one large, one medium, and one small ant-following antbird, while Amapá has two medium and two small ant-following antbirds. The two medium species separate mainly as second-growth versus forest birds, while the two small antbirds separate little except for $\mathrm{H}$. poecilonota being a slow and high forager compared to the volatile and low $P$. albifrons.

The Amapá guild has three woodcreepers lacking in Panamá; the very large Hylexetastes perrotti, the large Dendrocolaptes picumnus, and locally the medium-sized Dendrocincla merula. To some extent these woodcreepers take the place of large antbirds, for they all forage near the ground. However, all but $D$. merula compete most effectively above the ground. It is not evident how $D$. merula avoids competition with the smaller antbirds at such places as Reserva Ducke.

The Amapa guild is clearly larger than the Panamá guild, and it is also larger than the guild Oniki has studied at Belém (Oniki, MS). The Belém guild is dominated numerically by Pyriglena leuconota, a second-growth antbird of about the size and actions of Percnostola rufifrons, by a large antbird (Phlegopsis nigromaculata) of just under the size of the Panamanian Phaenostictus mcieannani, and by Dendrocincla fuliginosa. Dendrocincla merula, Dendrocolaptes certhia, and Hylophylax poecilonota are uncommon. Possibly $P$. nigromaculata is a big version of $G$. rufigula and $P$. leuconota a big version of $P$. albifrons, but the correspondences are mainly in numbers and behavioral cominance rather than in size. Possibly the absence of big woodcreepers $(H$. perrotti and $D$. picumnus) at Belém allows the two main antbirds to be large ones.

The guild at Belém shows more similarities to the Panamá guild than to the Amapá guild, even though the latter is just across the mouth of the Amazon and lives under a climate like that of Belém: both the Panamá and Belém 
çuilds have a large, a medium, and a small antbird; both have a common medium-sized and a rare large woodcreeper; and both have the generalist Eucometis penicillata, the latter confined mainly to tidally flooded woodland at Relém and to low forest (woodland) in Panamá The rare woodcreeper $D$. merula is an addition unrepresented in Panamá, except by the local $D$. homochroa of submontane Pacific woodlands, but otherwise the guilds are similar.

\section{ACKNOWLEDGEMENTS}

We gratefully acknowledge the assistance ot grants from the Frank M. Chapman Found of the American Museum of Natural History and the Conselho Nacional de Pesquisas (CNPq) of Erazil for Oniki's work at Serra do Navio, a fellowship of the Chapman Fund for Willis' work at Reserva Ducke, and a predoctoral grant from the National Science Foundation for Willis' studies at Nappi and Bartica. The kind help of Sub-director Carlos A. Marotta and many others of ICOMI (Indústria e Comércio de Minérios (.A.) and IPEAN (Instituto de Pesquisas e Experimentação Agropecuárias do Norte) made the studies at Serra do Navio possible, and the help of Director Djalma Batista and others of the staff of INPA (Instituto de Pesquisas da Amazonia) at Manaus and Reserva Ducke was rually welcome. The kind assistance of Ram S. Singh of the Georgetown Museum is appreciated. At Bartica, Willis was helped by Ivan A. Welch and others of the Forestry Department. We appreciate also the identifications of army ants by Roger Akre of Washington State University, and a critical reading by Philip S. Humphrey of the University of Kansas. Eugene Eisenmann, Dean Amadon, and Kenneth C. Parkes and the Amoricen Museum of Natural History and Carnegie Museum were most helpful in specimen studies.

\section{SUMÁRIO}

Nas florestas tropicais ao norte do rio Amazonas e ao este do Rio Negro, o grupo de aves que regularmente seguem as correiçōes das formigas taócas (principalmente Eciton burchelli) a fim de capturar artrópodos que tentam escapar das formigas inclui pelo menos 9 espécies profissionais : dois formicarídeos de tamanho médio (Gymnopithys rufigula e
Percnostola rufrifrons) e dois menores (Pithys albifrons e Hylophylax poecilonota); e 5 dendrocolaptideos, o muito grande Hylexetastes perrotti, o grande Dendrocolaptes picumnus, o levemente menor Dendrocolaptes certhia, e os de tamanho médio Dendrocincla merula e Dendrocincla fuliginosa. Na Serra do Navio e Reserva Ducke no Brasil e em Nappi e Bartica na Guiana, foram encontradas 6-9 espécies de aves seguidoras de correição. Quatro espécies adicionais, dois formicariídeos grandes, um cuculídeo grande e um tanagrídeo médio, provavelmente profissionais não foram observadas, embora relatadas localmente ou periferalmente na região.

Percnostola rufifrons ocorre em vegetação secuncária ou às margens das florestas. Junto às formigas, ela tende a obter alimentos saltando rapidamente ao chão. Hylophylax poecilonota, que ocorre nas matas, espera pacientemente em ramos mais altos e periodicamente salta rapidamente ao chão para obter o seu alimento. Pithys albifrons tende a aparecer junto às correições mais tarde e move-se mais rapidamente entre ramos mais altos e menores que os usados por Gymnopithys rufigula, que é a espécie dominante sobre todas as demais. Gymnopithys rufigula geralmente se põe centralmente, e próximo ao chão, isto é, nas melhores horas e lugares para obter alimentos Entretanto, os formicarídeos superpõem em seus nichos, e as aves de tamanho médio regularmente suplantam as aves menores.

Entre os dendrocolaptídeos, Dendrocolaptes picumnus vai para perto do chão para obter seus alimentos. Dendrocincla fuliginosa permanece um pouco mais acima e Dendrocolaptes certhia permancze mais alto ainda. Estas aves de olhos pequenos capturam alimentos em níveis mais baixos no meio do dia, sugerindo que elas esperam até que os niveis baixos tenham mais luz antes de se aventurarem nostes níveis. Hylexestastes perrotti são raras em todas as áreas estudadas; Dendrocincla merula parece ser regional, pois elas ocorrem só na Reserva Ducke e se alimentam próximo ao chão em direta competição com os formicarídeos. Dendrocincla fuliginosa locomovem-se para o alto quando competindo com os formicariídeos profissionais e com Dendrocolaptes picumnus. Entretanto, Dendrocincla merula permanece em níveis baixos e talvez encontre alimentos movendo-se rapidamente para áreas localmente pro. dutivas. Todos os dendrocolaptídeos pousam em grandes troncos verticalmente enquanto que os formicariídeos usam ramos menores tanto verticais como horizontais. Em média, os dendrocolaptídeos capturam a maioria das presas em niveis médios ci mata e os formicarídeos capturam a maioria das prêsas próximas ao chão.

Quarenta e cinco espécies de aves não profissionas ou amadoras em seguir as formigas de correição loram observadas na região. Dezesseis espécies eram fermicarifideos, cinco eram dendrocolaptídcos e cinco eram piprídeos. Entretanto, as aves amadoras 
mais persistentes pertenciam às familias Cotingidae (Attila spadiceus), Troglodytidae (Henicorhina leucosticta) e Parulidae (Basileuterus rivularis).

A maioria das aves seguidoras amadoras de cor. reiçōes saltam ou caminham nas bordas das correições, infilltram-se entre as folhagens de 0.5 a $2 \mathrm{~m}$ dc eltura entre as zonas utilizadas pelos formicarifideos e dendrocolaptídeos profissionais ou permanecem no alto e nas zonas menos produtivas (acima da zona uilizada pelos dendrocolaptídeos). Os formicarif. deos amadores são menos ativos no meio da manhã quando os formicarí́deos profissionais são mais ativos. O número de aves amadoras em seguir as correiçōes diminui quando se passa de vegetação səcundária e borda de mata para densa floresta. Os clendrocolaptídeos profissionais são mais comuns na mata ou nas bordas enquanto que os formicariídeos profissionais predominam em extensivas matas altas.

\section{LITERATURE CITED}

ARAúJo, V. C. DE

1967 - A reserva florestal Reserva Duck (Manaus) : Características e principais elementos florísticos e faunísticos protegidos. Atas Simp. sôbre Biota Amaz., 7 (Conservação da natureza e recursos naturais) : $57-68$.

BEeBE, C. W. ET ALII

1917 - Tropical wild life in British Guiana. Nev York, New York Zool. Soc., v. 1, 504 p.

EISENMANN, E.

1952 - Annotated list of birds of Barro Colorado Island, Panamá Canal Zone. Siniths. Misc Coll., 117(5) : 1-62.

Frost, D. B.

1968 - The climate of the Rupununi savannahs (Guyana). Technical Report. McGill University Department of Geography, 13: 1-92.

GILLIARD, E. T,

1962 - On the breeding behavior of the Coc.:-of-the Rock (Aves, Rupicola rupicola), Buil, Am Mus. Nat. Hist., New York, 124: 31-68.

HAVERSCHMIDT, F.

1968 - Birds of Surinam. Edinburgh and London, Oliver and Boyd, $446 \mathrm{p}$.

Heimerdinger, M. A. \& AMEs, P. L.

1967 - Variation in the sternal notches of suboscin: passeriform birds. Postilla, New Hıven, Conn., $105: 1-44$

HOWELL, T. R.

1957 - Birds of a second-growth rain forest area of Nicaragua. Condor, 59: 73-111.

JoHNSON, R. A.

$1954^{\mathrm{m}}$ - The behavior of birds attending army ant rai: on Barro Colorado Island, Panamá Canal Lenc Proc, Linn. Soc, N, Y., 63-65: 41. J
MEyer de Schauensee, $R$.

1965 - The birds of South America and their distri. bution. Narberth, Pa,, Livingston Publ. Co 578 p.

Novaes, F. C.

1957 - Notas de ornitologia Amazônica. I. Gênero Formicarius e Phlegopsis. Bot. Mus, Par. Emilio Goeldi, nova série: Zoologia, 8 : 1-8.

ONIKI, $\mathrm{Y}$,

1 y70 - Roosting behavior of three species of woocreepers (Dendrocolaptidae) in Brazil. Condor $72: 233$

Phelps, W. H. \& Phelps, JR., W. H.

1963 - Lista de las aves de Venezuela con su distribution. Tome 1, parte II - Passeriformes, 2. ed. Caracas, Editorial Sucre, $479 \mathrm{p}$.

RETTENMEYER, C, W.

1963 - Behavioral studies of army ants. Univ, Kans Sci. Bull., $44: 281-465$.

RUDRIGUES, W. A

1963 - Estudo de 2,6 hectares de mata de terra firme da Serra do Navio, Território do Amapa. boi Mus. Par. Emílio Goeldi, nova série: Botâ. nica, $19: 1-22$.

К๐OT, R. B .

1967 - The niche exploitation pattern of the Blue-gray Gnatcatcher. Ecol. Monogr., Durham, 37: 317-350.

SChINEIRLA, T, C.

$1 \gg 37$ - A comparison of species and genera in thะ ant subfamily Dorylinae with respect to functicnal pattern. Insectes Soctaux, Paris, 4 : 259-298.

SLUD, $P$.

1960 - The birds of Finca "La Selva", Costa Rica : A tropical wet forest locality. Bull. Amer. Mus Nat. Hist., New York, 121(2): 49-148.

SNYDER, D. E.

1966 - The birds of Guyana. Salem, Mass., Peabody Museum. 308 p.

WiLLIS, E.

1960 - A study of the foraging behavior of two species of ant-tanagers. Auk, 77: 150-170.

1966 - Interspecific competition and the foraging behavior of Plain-brown Woodcreepers. Ecology, Brooklyn, 47 : 667-672.

i967 - The behavior of Bicolored Antbirds. Univ. Cal. Publ. Zool., $79: 1-132$.

$1968 \mathrm{a}$ - Studies of the behavior of Lunulated and Salvin's Antbirds. Condor, 70: 128-148.

1968b- Taxonomy and Behavior of Pale-faced Antbirds. Auk, 85: 253-264.

1969 - On the behavior of five species of Rhegmatorin $n c$, ant-following antbirds of the Amazon ba sin. Wilson Bull., 81: 363-395 
Species - NAPPI

Rufous-thr. Antbird

White-pl. Antbir

Black-h. Antbird

Plack-b. Woodcreeper

Plain-br. Woodcreeper

Barred Woodcreeper
Red-billed Woodcreeper

Wedge-b. Woodcreeper

Buff-thr. Woodcreeper

Cinereous Antshrike

Dusky-thr. Antshrike

Warbling Antbird

White-browed Antbird

White-bellied Antbird

Ferr.-b. Antbird

Black-f. Antthrush

Rufous-c. Antthrush

Gray-w. Trumpeter

Ringed Antpipit

River Warbler

Pectoral Sparrow

White-b. Woo Thrush

White-n. Thrush

Lined Forest-Falcon

Bright-r. Attila

Black Nunbird

Other Antbirds (5 spp.)

Others

SERRA DO NAVIO

White-pl, Antbird

Rufous-thr. Antbird

Black-h. Antbird

Scale-b, Antbird

Black-b. Woodcreeper

Plain-br. Woodcreeper

Barred Woodcreeper

Red-bill. Woodcreeper

Wedge-b. Woodcreeper

Chest.-r. Woodcreeper

Spot-th. Woodcreeper

Cinereous Antshrike

Mouse_col Antshrike

Warbling Antbird

Chest.-b. Gnateater

Spot-back. Antbird

River Warbler

White-b. Wood-Wren

White-cr. Manakin

a - including heights of food capture and travel records

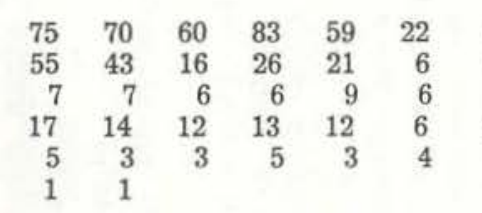

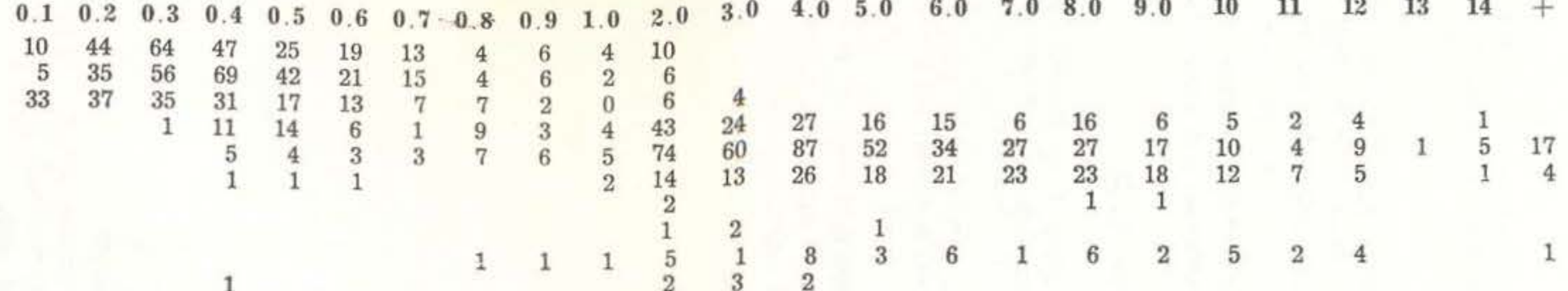

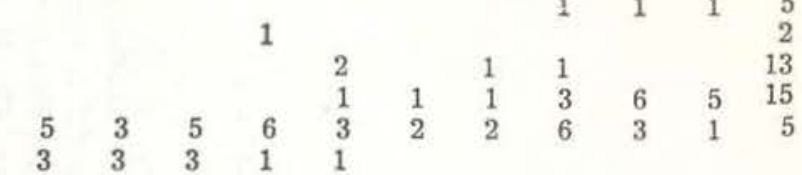



1



1

$\begin{array}{lll}4 & 1 & 2 \\ 1 & 1 & 1\end{array}$

1

$\begin{array}{rllllllllll}1 & 1 & & & 1 & 3 & 1 & 2 & 1 & 1 & \\ 4 & 1 & & 1 & 1 & 1 & & & & 1 & \\ 3 & 3 & 2 & 1 & & & & & & 2 & 3 \\ 7 & 7 & 2 & 3 & 3 & 2 & & & & 2 & \\ 3 & 4 & 3 & 3 & 2 & 1 & & & & & \\ 10 & 1 & 1 & 1 & & & & & & 3 & \\ 4 & 1 & 1 & 1 & 2 & 1 & 1 & 1 & & 3 & 1 \\ & & & & & & & & & 1 & 1\end{array}$

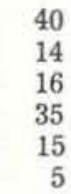

5
4 31 $\begin{array}{rrrrrrrrrrrrr}9 & 10 & 5 & 3 & 2 & 2 & 1 & 1 & & & & 1\end{array}$$$
6
$$ 
NAPPI

White-plumed Antbird

Rufous-thr. Antbird

Black-headed Antbird

Plain-brown Woodcreeper

Barred Woodcreeper

Black-banded Woodcreeper

Red-billed Woodcreeper

Buff-thr. Woodcreeper

Wedge-billed Woodcreeper

Cinereous Antshrike

Dusky-throated Antshrike

Warbling Antbird

White-browed Antbird

White-bellied Antbird

Other antbirds

River Warbler

White-breasted Wood-Wren

Lined Forest-Falcon

Bright-rumped Attila

Black Nunbird

Others

\section{SERRA DO NAVIO}

White-plumed Antbird

Rufous-throated Antbird

Black-headed Antbird

Scale-backed Antbird

Black-banded Woodcreepe

Plain-brown Woodcreeper

Barred Woodcreeper

Red-billed Woodcreeper

Wedge-billed Woodcreeper

Chestnut-r. Woodcreeper

Spot-throated Woodcreeper

Cinereous Antshrike

Mouse-colered Antshrike

Warbling Antbird

Chestnut-belted Gnateater

Spot-backed Antbird

River Warbler

White-breasted Wood-Wren

White-crowned Manakin

\begin{tabular}{|c|c|c|c|c|c|c|c|c|}
\hline $0.20^{\circ}$ & $.40^{\circ}$ & $.60^{\circ}$ & $.80^{\circ}$ & $.100^{\circ}$ & $.120^{\circ}$ & $-140^{\circ}$ & $.160^{\circ}$ & $180^{\circ}$ \\
\hline 31 & 16 & 5 & 12 & 139 & & & & \\
\hline 20 & 11 & 3 & 4 & 63 & & & & \\
\hline 30 & 7 & 3 & 8 & 37 & & & & \\
\hline \multirow[t]{4}{*}{1} & 1 & 4 & 35 & 343 & 3 & & 1 & 1 \\
\hline & & 4 & 15 & 148 & 10 & 1 & & \\
\hline & 1 & 1 & 15 & 170 & 11 & 1 & & 1 \\
\hline & & & 1 & 3 & & & & \\
\hline \multirow[t]{2}{*}{2} & 2 & 2 & 6 & 28 & 2 & 1 & 1 & \\
\hline & & & & 4 & & & & \\
\hline
\end{tabular}

$\begin{array}{rrrrrrr}77 & 14 & 55 & 20 & 189 & \\ 38 & 8 & 28 & 9 & 58 & 1 & 3 \\ 22 & 5 & 10 & 2 & 12 & & \\ 13 & 3 & 20 & 7 & 78 & \\ 2 & & 2 & 1 & 62 & \\ & & 1 & 4 & 56 & \\ & & & & 8 & \\ & & & & 9 & \\ & & & 1 & 7 & \\ 1 & & & 2 & 19 & \\ & & & 1 & 1 & \\ 13 & 1 & 1 & 1 & 5 \\ 5 & 1 & 1 & & 1 \\ 6 & 2 & 3 & & 5 \\ 3 & 2 & 3 & 2 & 15 \\ & 1 & 2 & 1 & 8 & \\ 9 & 2 & 3 & & & \\ 5 & & 2 & 1 & 6 \\ 11 & 6 & 7 & & 2\end{array}$




\section{APPENDIX 3}

Perch Diameters

\begin{tabular}{|c|c|c|c|c|c|c|c|c|c|}
\hline NAPPI $\quad \because \ldots \quad \ldots \ldots$ & 1 & 2 & 3 & 4 & 5 & $\mathbf{A}^{t}$ & B & C & D \\
\hline White-plumed Antbird & 114 & 72 & 8 & 4 & 3 & 1 & & & \\
\hline Rufous-thr. Antbird & 42 & 42 & 6 & 4 & 2 & 2 & & & \\
\hline Black-headed Antbird & 26 & 39 & 8 & 4 & 2 & 1 & & & \\
\hline Plain-brown Woodcreeper & 1 & 6 & 17 & 46 & 39 & 175 & 76 & 25 & 5 \\
\hline Barred Woodcreeper & & & & 1 & 6 & 61 & 64 & 36 & 4 \\
\hline Black-banded Woodcreeper & & 2 & 6 & 6 & 2 & 72 & 65 & 29 & 8 \\
\hline Red-billed Woodcreeper & & & & & & 1 & 1 & 2 & \\
\hline Buff-thr. Woodcreeper & & 2 & & & & 20 & 11 & 5 & 3 \\
\hline Wedge-billed Woodcreeper & & 1 & & & & 1 & 2 & & \\
\hline Cinereous Antshrike & & 1 & & & & & & & \\
\hline Dusky-throated Antshrike & 6 & 4 & & & & & & & \\
\hline Warbling Antbird & 10 & 1 & 2 & & & & & & \\
\hline White-browed Antbird & 6 & 7 & 2 & & 3 & 3 & & & \\
\hline White-bellied Antbird & & 1 & 1 & & & & & & \\
\hline Other antbirds & & & & 2 & & & & & \\
\hline River Warbler & 2 & & 1 & & 1 & & & & \\
\hline White-breasted Wood-Wren & 3 & 1 & & & & & & & \\
\hline Lined Forest-Falcon & 1 & 2 & 2 & & & & & 2 & \\
\hline Bright-rumped Attila & 4 & 6 & 6 & 1 & & 1 & & & \\
\hline Black Nunbird & 2 & 5 & 4 & 1 & 1 & & & & \\
\hline Others & 4 & 2 & & & & & & & \\
\hline
\end{tabular}

\section{SERRA DO NAVIO}

White-plumed Antbird
Rufous-throated Antbird
Black-headed Antbird
Scale-backed Antbird
Plain-brown Woodcreeper
Barred Woodcreeper
Black-banded Woodcreeper
Red-billed Woodcreeper
Chestnut-rumped Woodcreeper
Wedge-billed Woodcreeper
Spot-throated Woodcreeper
Cinereous Antshrike
Mouse-colered Antshrike
Warbling Antbird
Chestnut-belted Gnateater
Spot-backed Antbird
Piver WarbleP
White-br. Wood-Wren
White-crowned Manakin

\begin{tabular}{|c|c|c|c|c|c|c|}
\hline 246 & 55 & 5 & 2 & 10 & & 5 \\
\hline 97 & 33 & & 2 & 12 & & 1 \\
\hline 22 & 12 & 1 & & 6 & 1 & \\
\hline 81 & 18 & 1 & & 5 & & \\
\hline & 4 & 5 & 1 & 38 & 6 & 4 \\
\hline & & & & 5 & 2 & 1 \\
\hline$\because$ & 7 & 1 & 2 & 37 & 13 & 6 \\
\hline 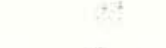 & & & 1 & 5 & 1 & 1 \\
\hline 1 & 6 & 2 & & 9 & 4 & 2 \\
\hline & & 1 & & 3 & 3 & 3 \\
\hline
\end{tabular}

1. $\mathrm{A}=5-14 \mathrm{~cm}$., $\mathrm{B}=15-24 \mathrm{~cm}$., $\mathrm{C}=25-49 \mathrm{~cm}$., $\mathrm{D}=50-99 \mathrm{~cm}$., $\mathrm{E}=100 \mathrm{~cm}$. plus. 
TABLE 3

Per Cent of Prey Captures (P) and Records (R) of Birds at Ant Swarms

\begin{tabular}{|c|c|c|c|c|c|c|c|c|}
\hline & \multicolumn{2}{|c|}{$\begin{array}{c}\text { Serra do Navio } \\
(P=150, R=971)\end{array}$} & \multicolumn{2}{|c|}{$\begin{array}{r}\text { Reserva Ducke } \\
(P=53, R=429)\end{array}$} & \multicolumn{2}{|c|}{$\begin{array}{c}\text { Nappi } \\
P=654, R=4855)\end{array}$} & \multicolumn{2}{|c|}{$\begin{array}{c}\text { Bartica } \\
(\mathrm{P}=24, \quad \mathrm{R}=342\end{array}$} \\
\hline & $\mathbf{P}$ & $\mathbf{R}$ & $\mathbf{P}$ & $\mathbf{R}$ & $\mathbf{P}$ & $\mathbf{R}$ & $\mathbf{P}$ & $\mathbf{R}$ \\
\hline Rufous-throated Antbird & $16.7 \%$ & 17.1 & 11.3 & 41.9 & 16.8 & 32.4 & 20.8 & 56.1 \\
\hline White-plumed Antbird & 30.0 & 30.6 & 37.7 & 26.8 & 20.4 & 20.5 & 12.5 & 27.2 \\
\hline Black-headed Antbird & 6.0 & 6.2 & 3.8 & 2.1 & 7.5 & 5.4 & - & - \\
\hline Scale-backed Antbird & 9.3 & 7.1 & - & - & - & 0.02 & 12.5 & 1.8 \\
\hline Plain-brown Woodcreeper & 4.0 & 9.2 & 9.4 & 5.6 & 19.6 & 14.5 & 45.8 & 9.3 \\
\hline White-chinned Woodcreeper & - & - & 18.9 & 12.8 & - & - & - & - \\
\hline Black-banded Woodcreeper & 10.0 & 6.5 & 5.7 & 4.7 & 7.4 & 5.9 & 4.2 & 3.2 \\
\hline Barred Woodcreeper & - & 0.6 & 1.9 & 0.5 & 8.3 & 5.5 & 4.2 & 1.2 \\
\hline Red-billed Woodcreeper & - & 0.6 & 1.9 & 0.9 & 0.3 & 0.3 & - & - \\
\hline Nonprofessionals & 24.0 & 22.1 & 9.4 & 4.7 & 19.7 & 15.5 & 一 & 1.2 \\
\hline
\end{tabular}

TABLE 4

Commonest Birds at swarms of Eciton burchelli

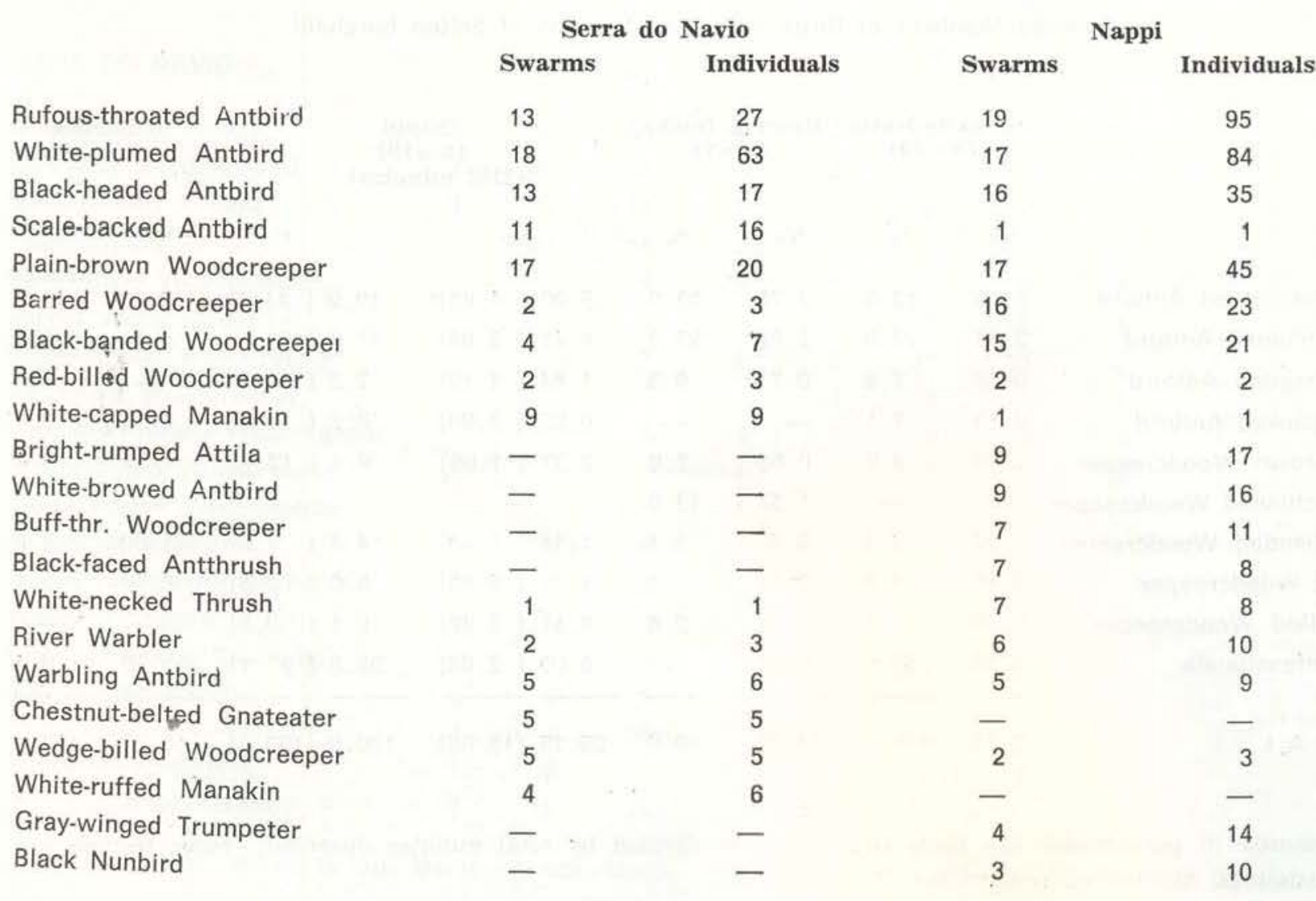


TABLE 5

Records Per Hour at Different Times of Day

Records/hour Observed

SERRA DO NAVIO

HOUR

TOTAL

Rufous-thr. Antbird

White-pl. Antbird

Black-h. Antbird

Scale-b. Antbird

Plain-br. Woodcreeper

Black-b. Woodcreeper

Barred Woodcreeper

Red-billed Woodcreeper

Nonprofessionals

TOTAL

Rufous-thr. Antbird

White-pl. Antbird

Black-h. Antbird

Scale-b. Antbird

Plain-br. Woodcreeper

Black-b. Woodcreeper

Barred Woodcreeper

Red-billed Woodcreeper

Nonprofessionals

$\begin{array}{rccccccccccc}6 & 7 & 8 & 9 & 10 & 11 & 12 & 13 & 14 & 15 & 16 & 17 \\ 3.7 & 7.5 & 10.1 & 8.7 & 10.2 & 8.9 & 5.9 & 8.1 & 4.7 & 1.5 & 2.0 \\ 0.5 & 0.7 & 2.4 & 1.7 & 1.4 & 1.0 & 1.2 & 2.0 & 0.7 & 0.6 & - \\ 0.3 & 2.4 & 2.7 & 2.7 & 3.6 & 3.0 & 1.9 & 2.4 & 1.7 & 0.7 & 2.0 \\ 1.6 & 0.7 & 0.6 & 0.2 & 0.2 & 0.2 & 0.1 & 0.3 & 0.4 & - & - \\ 0.3 & 0.7 & 0.6 & 0.3 & 1.0 & 0.9 & 0.2 & 0.8 & 0.2 & 0.2 & - \\ 0.2 & 0.8 & 0.9 & 0.9 & 0.8 & 0.9 & 0.6 & 0.9 & 0.1 & - & - \\ - & 0.3 & 1.0 & 0.7 & 0.9 & 0.5 & 0.6 & - & - & - & - \\ - & - & 0.2 & 0.1 & 0.1 & - & - & - & - & - & - \\ - & - & 0.1 & 0.05 & 0.2 & - & - & - & - & - & - \\ 0.8 & 1.9 & 1.6 & 2.1 & 2.0 & 2.4 & 1.3 & 1.7 & 1.6 & - & -\end{array}$

NAPP I

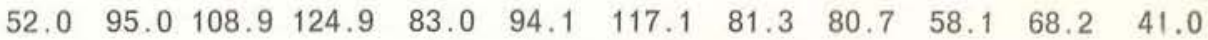

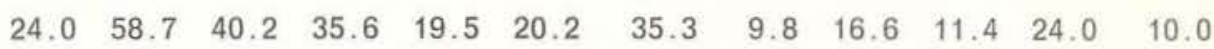

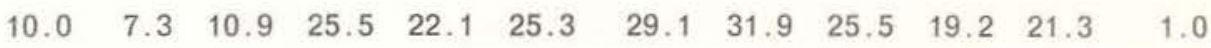

$\begin{array}{lllllllllll}6.0 & 8.6 & 3.6 & 4.5 & 2.5 & 5.2 & 6.6 & 0.8 & 3.3 & 2.2 & 15.9\end{array}$

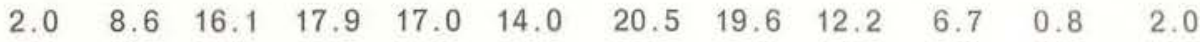

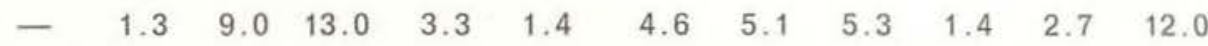

$\begin{array}{llllllllllll}- & 1.2 & 6.1 & 5.8 & 6.2 & 11.1 & 8.2 & 5.1 & 5.3 & 0.8 & 1.9 & -\end{array}$

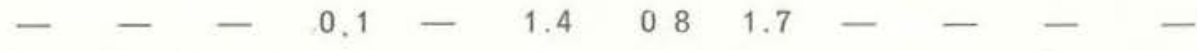

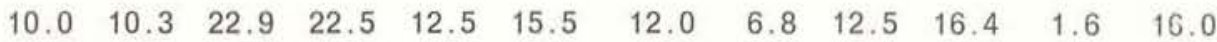

